\title{
The Ectopic Germinal Centre Response in Autoimmune Disease and Cancer
}

\author{
David I. Stott and Donna McIntyre \\ Institute of Infection, Immunity $\mathcal{E}$ Inflammation, University of Glasgow, Glasgow, \\ Scotland, U.K.
}

\section{Introduction}

\subsection{The B-cell response in autoimmune disease}

The pathological effects of autoimmune diseases on the target tissues can be mediated by autoantibodies, cell-mediated immune responses, or both. It is increasingly evident that some autoimmune diseases previously thought to be essentially T-cell-mediated also have a B-cell component, which may involve direct effects of autoantibody secreted by plasma cells, pro- or anti-inflammatory cytokines secreted by activated effector or regulatory B-cells, or through the highly efficient antigen presentation function of B-cells enabling them to activate CD4 $4^{+} \mathrm{T}$-cells and vice versa. The number of autoimmune diseases known to be mediated partly or largely through autoantibodies has increased markedly in recent times. Systemic lupus erythematosus $(\mathrm{SLE})^{1}$, in which the pathology is mediated via Type II \& III hypersensitivity reactions involving anti-DNA autoantibodies, has long been known to fall into this category. Many other autoantibodies are produced by these patients, principally against nuclear antigens, but most are not thought to be involved in pathology. Hashimoto's thyroiditis and Graves' disease patients produce pathogenic autoantibodies against thyroid antigens, the latter being a rare example of an activating autoantibody inducing signalling via the thyroid stimulating hormone receptor. Myasthenia gravis patients produce autoantibodies against the acetylcholine receptor (AChR), present on the motor muscle endplates, thereby inhibiting muscle contraction. Anti-SS-A and anti-SS-B (anti-Ro \& anti-La) autoantibodies are implicated in congenital heart block in children born to mothers with Sjögren's Syndrome due to transplacental uptake of IgG autoantibodies; autoantibodies against a-fodrin are also believed to be pathogenic in these patients. Rheumatoid arthritis (RA), one member of the group of systemic rheumatic autoimmune diseases that also includes SLE, psoriatic arthritis and the various forms of myositis, has now gone full cycle in views on its pathological mechanisms.

\footnotetext{
1 Abbreviations: AChR, Acetylcholine Receptor; AID, Activation Induced Cytidine Deaminase; AMC, Arthrogryposis Multiplex Congenita; ARS, Anti-amino acyl-tRNA Synthetase; Bmem, Memory B-cell; CDR, Complementarity Determining Region; DM, Dermatomyositis; EOMG, Early Onset Myasthenia Gravis; FDC, Follicular Dendritic Cell; G.C., Germinal Centre; IBM, Inclusion Body Myositis; IM, Inflammatory Myopathies; LOMG, Late Onset Myasthenia Gravis; MAA, Myositis-Associated Autoantibodies; MAb, Monoclonal Antibody; MIR, Main Immunogenic Region; MSA, Myositis Specific Autoantibodies; PM, Polymyositis; RA, Rheumatoid Arthritis; SLE, Systemic Lupus Erythematosus; TAA, Tumour-Associated Antigen; TIL, Tumour-Infiltrating Lymphocytes; Tfh, Follicular T helper cell; UNG, Uracil Nucleotidyl Glycosylase.
} 
Initially thought to be caused by the anti-IgG Fc antibody (rheumatoid factor), although approximately $25 \%$ of RA patients are rheumatoid factor negative, the evidence then swung in favour of a cell mediated autoimmune response involving effector T-cells and cytokines, principally TNFa. Although these are clearly involved in joint pathology, autoantibodies against cyclic citrullinated proteins are a much better diagnostic marker for RA than rheumatoid factor and there is some limited evidence that they may be pathogenic. It is also now recognised that B-cells play an important role in the pathogenic autoimmune response, as clearly demonstrated by the marked clinical improvement in patients treated with Rituximab®, an anti-CD20 chimaeric (human/mouse) monoclonal antibody that suppresses Bcell responses. Other autoimmune diseases with B-cell involvement include autoimmune haemolytic anaemia, idiopathic thrombocytopaenia, Type I diabetes, and some subtypes of myositis, although the situation is often confused by the presence of non-pathogenic autoantibodies.

\subsection{The germinal centre response to foreign antigens}

Germinal centres (g.c.) are the main sites of generation of high affinity, antibody-secreting plasma cells and Ig class-switched memory B-cells during T-cell-dependent immune responses, extensively reviewed by others (Allen, Okada, \& Cyster, 2007; Brink, 2007; Hauser, Shlomchik, \& Haberman, 2007; Klein \& Dalla-Favera, 2008; Leavy, 2010; Minton, 2011). Here we shall summarise briefly the principal features of the g.c. response. The response is initiated by B-cells binding to their cognate antigen on the surface of antigen presenting cells, such as dendritic cells, in a secondary lymphoid organ (lymph node, spleen, Peyer's patches or human tonsil). The antigen becomes internalised, degraded into peptides which are expressed on the cell surface bound to MHC Class II and presented to a helper $\mathrm{T}\left(\mathrm{T}_{\mathrm{h}}\right)$ cell that provides costimulatory activation signals, including binding of the Bcell surface molecule CD40 to its ligand, CD154, on the T-cell membrane.

This interaction takes place at or near the interface between the B-cell follicle and the T-cell area and some activated B-cells proliferate outside the follicle and differentiate into short-lived plasma cells secreting IgM antibodies. Others migrate into the B-cell follicle where they proliferate and differentiate into centroblasts expressing low levels of surface Ig. This region develops into a germinal centre with a dark zone of densely packed, proliferating centroblasts, and a light zone of more loosely packed B-cells (centrocytes) interspersed with the processes of follicular dendritic cells (FDC, Figure 1A). These have distinct stromal origins, unlike the bone marrow derived, extra-follicular dendritic cells; almost uniquely, their $\mathrm{C}^{\prime}$ and $\mathrm{Fc}$ receptors trap immune complexes and retain antigens in their native state for months.

The pre-existing $\operatorname{IgM}^{+}, \operatorname{IgD}^{+}$follicle B-cells are pushed out to form a mantle zone around the developing germinal centre, the whole structure being termed a secondary follicle. Proliferation of the dark zone centroblasts is extremely rapid, with cell cycle times estimated at between 6 and 12 hours. These proliferating clones of B-cells switch on the molecular machinery required for somatic hypermutation of their rearranged, expressed, Ig V-genes, including expression of activation-induced cytidine deaminase (AID). This induces mutations specifically targeted to the Ig V-genes at a frequency of 1 per 1000 base pairs per cell division, although much lower levels of mutation can also occur in some other, non-Ig genes such as Bcl-2 \& Bcl-6. AID deaminates cytidine to uracil at $\mathrm{C} / \mathrm{G}$ base pairs, introducing mismatches in the DNA that can be replaced by $\mathrm{T} / \mathrm{A}$ base pairs. Uracil nucleotidyl glycosylase (UNG) can remove the uracil leading to insertion of any of the four bases at the abasic site; mismatch repair enzymes also recognise the mismatch and induce 
single strand breaks which are repaired by error prone DNA polymerases (Di Noia \& Neuberger, 2007). The mutations are targeted mainly to the complementarity determining regions (CDRs) which are intimately involved in binding to the epitope and therefore determine specificity and affinity of the antibody. Combined with the rapid proliferation, this results in clones of B-cells expressing receptors with a variety of affinities for the antigen, some high, some low; some will have lost the ability to bind to the antigen altogether and rare B-cells may cross-react with a self-antigen.

Several clones of proliferating, mutating B-cells are usually present within each germinal centre. These cells differentiate into centrocytes expressing mutated antigen receptors and migrate into the light zone. The centrocytes move through the light zone, acquire antigen for a second time from immune complexes on the follicular dendritic cells, which they internalise, process and present to follicular helper $\mathrm{T}$-cells ( $\mathrm{T}_{\mathrm{fh}}$-cells) (Patakas et al., 2011), thereby receiving survival signals, probably via costimulatory molecule interactions including CD40/CD154 and CD80/CD28 binding. These signals, together with $\mathrm{T}_{\mathrm{fh}}$-cell cytokines (IL-4 and IFNY) and AID deamination of cytidines, promote induction of class switch recombination (Patakas et al., 2011). Some of these centrocytes differentiate directly into plasmablasts and antibody-secreting plasma cells; others differentiate into Ig class switched memory B-cells, both of which migrate out of the follicle. Competition for limiting availability of antigen results in selection of B-cells expressing high affinity antigen receptors; recent evidence has shown that a broad range of mutations is involved in selection, not only for high affinity receptors but also for stability and expression of the Bcell receptor (Weiser et al., 2011). Cells expressing antigen receptors with low affinity are unable to compete for survival signals and the default response is that they die by apoptosis and are engulfed by macrophages, in which their degenerating nuclei are visible as tingible bodies. Most of this information is derived from studies in mice, in which the germinal centres reach maximum size about two weeks after immunisation and then gradually decline in the absence of further immunisation, disappearing after several weeks. Although the cell composition and structure of secondary follicles appear similar in Man, the kinetics and some of the detailed cellular interactions may differ.

Detailed studies of the kinetics and cellular interactions within germinal centres using multiphoton microscopy of living tissue in combination with B \& T-lymphocytes expressing defined antigen receptors from transgenic animals have revealed much more dynamic activity than was previously suspected. It is now recognised that there is less distinction between the dark and light zones than suggested by static immunohistological examination, and there is continual recycling of B-cells both between and within the two zones, although there is net migration from the dark zone to the light zone (Beltman et al., 2011)(Figure 1B). Centrocytes move rapidly through the network of follicular dendritic cell processes, apparently sampling the immune complexes attached to their membranes and some of these cells return to the dark zone for further rounds of proliferation and somatic hypermutation. Migration of B-cells between the zones is controlled by chemokines, possibly secreted by stromal cells within the germinal centre. $\mathrm{T}_{\mathrm{fh}}$-cells are present mainly in the light zone and recent data suggest that affinity selection of B-cells may involve competition for signals from cognate $\mathrm{T}_{\mathrm{fh}}$-cells via peptide/MHC Class II binding as well as, or instead of, competition for antigen on the surface of follicular dendritic cells (Victora et al., 2010). Anti-self B-cells that have escaped negative selection in the bone marrow, or have arisen in the germinal centre due to somatic hypermutation, are either eliminated at this stage, suppressed by regulatory T-cells, or alter their antigen specificity by receptor revision, a process similar to V-gene rearrangement in 
developing B-cells. This involves re-expression of RAG1 and RAG2 and rearrangement of an upstream light chain V-gene to an unused J exon (Nemazee, 2006). Despite the absence of D exons in the rearranged heavy chain locus, we have shown that an upstream heavy chain Vgene can also replace all or part of a rearranged $\mathrm{V}_{\mathrm{H}^{-}}$-gene, thereby altering the specificity of the receptor away from self antigen (Darlow \& Stott, 2005). The architecture, cellular components and processes occurring in a typical germinal centre are summarised in Figure 1.

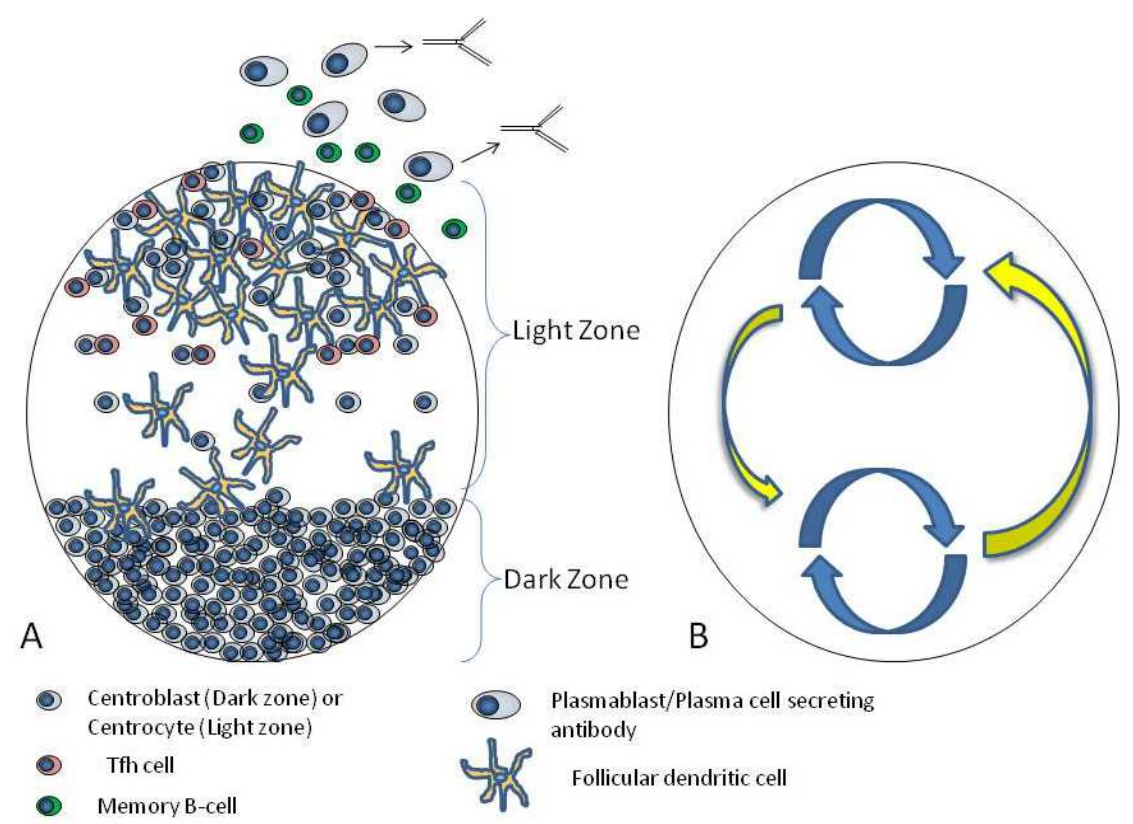

Fig. 1. Diagrammatic representation of a germinal centre in a lymph node.

A: Showing a dark zone containing proliferating clones of mutating centroblasts and a light zone containing centrocytes in contact with follicular dendritic cells and follicular helper T-cells (Tfh cells). Long-lived memory B-cells, plasmablasts and plasma cells secreting antibody molecules migrate out of the g.c. and leave the lymph node via the efferent lymphatic vessel. Apoptotic B-cells, macrophages containing tingible bodies and the mantle zone are not shown.

B: The same germinal centre showing recirculation of B-cells within and between the dark and light zones.

\subsection{The ectopic germinal centre response in autoimmune disease}

It has been known for many years that the target tissues of autoimmune diseases contain infiltrating lymphocytes and other immune cells, including T-cells, B-cells, plasma cells, macrophages, dendritic and follicular dendritic cells. In many cases the infiltrating cells organise themselves into structures resembling germinal centres. Some of these have a mantle zone, suggesting that they were formed from a primary follicle whereas, even when absent, it is often possible to distinguish a dark zone, containing few or no CD4 ${ }^{+} \mathrm{T}$-cells or follicular dendritic cells, and a light zone containing both. Autoantigens have been identified on the finger-like processes of follicular dendritic cells (Shiono et al., 2003) and, in some cases, autoantibodies have been identified in g.c. B-cells. Separate T-cell areas containing dendritic cells and, sometimes, high endothelial venules, can also be seen. The stage of lymphoid 
neogenesis appears to be directly related to the extent of infiltration of lymphoid and other immune cells (Aloisi \& Pujol-Borrell, 2006). Examples of autoimmune diseases in which germinal centre-like structures have been identified in the target, or disease-related tissues are shown in Table 1. It is now apparent that ectopic germinal centres, also known as tertiary lymphoid organs, can also develop in other chronic inflammatory diseases, such as the gut in Crohn's disease and ulcerative colitis patients, in chronic infections (Aloisi \& Pujol-Borrell, 2006) and some types of cancer (Table 1). The questions these observations raise are: 1 . How do they develop?; 2. How closely do they resemble germinal centres in secondary lymphoid organs?; 3 . Are the B-cells within them undergoing a germinal centre response, as described in section 1.2 above?; 4 . Are they generating plasma cells secreting pathogenic autoantibodies?; 5 . What role do they play in the pathogenesis of autoimmune disease?

\begin{tabular}{|c|c|c|c|}
\hline Autoimmune Diseases & \begin{tabular}{|l|} 
Organ containing \\
Germinal Centres \\
\end{tabular} & \begin{tabular}{|l} 
Antigen(s) Recognised \\
by GC B-cells
\end{tabular} & Reference \\
\hline Hashimoto's thyroiditis & Thyroid & $\begin{array}{l}\text { Thyroglobulin, } \\
\text { Thyroperoxidase }\end{array}$ & $\begin{array}{l}\text { (Knecht, Saremaslani, \& } \\
\text { Hedinger, 1981) } \\
\text { (Armengol et al., 2001) }\end{array}$ \\
\hline Graves' disease & Thyroid & \begin{tabular}{|l|} 
Thyroglobulin, \\
Thyroperoxidase
\end{tabular} & (Armengol et al., 2001) \\
\hline Myasthenia gravis & Thymus & Acetylcholine receptor & \begin{tabular}{|l} 
(Yoshitake et al., 1994) \\
(SHIONO et al., 2003)
\end{tabular} \\
\hline Sjögren's syndrome & \begin{tabular}{|l|} 
Salivary glands \\
\end{tabular} & SS-A (Ro), SS-B (La) & (Stott et al., 1998) \\
\hline Rheumatoid arthritis & $\begin{array}{l}\text { Synovial membranes } \\
\text { of joints }\end{array}$ & $\begin{array}{l}\text { IgG Fc, Cyclic citrullinated } \\
\text { protein/peptide }\end{array}$ & $\begin{array}{l}\text { (Manzo \& Pitzalis, 2007) } \\
\text { (Humby et al., 2009) }\end{array}$ \\
\hline Psoriatic arthritis & $\begin{array}{l}\begin{array}{l}\text { Synovial membranes } \\
\text { of joints }\end{array} \\
\end{array}$ & \begin{tabular}{|c|}
$?$ \\
\end{tabular} & \begin{tabular}{|l|} 
(Canete et al., 2007) \\
(Gerhard et al., 2002) \\
\end{tabular} \\
\hline $\begin{array}{l}\text { Cryptogenic fibrosing } \\
\text { alveolitis }\end{array}$ & Lungs & $?$ & (Wallace et al., 1996) \\
\hline Uveoretinits & Choroid of the eye & $?$ & (Liversidge et al., 1993) \\
\hline Autoimmune hepatitis & Liver & $?$ & (Mosnier et al., 1993) \\
\hline Multiple sclerosis & Meninges (?) & $?$ & (Prineas, 1979) (Serafini et al., 2004) \\
\hline \multicolumn{4}{|l|}{$\begin{array}{l}\text { Chronic Inflammatory } \\
\text { Diseases }\end{array}$} \\
\hline Crohn's disease & Gastrointestinal tract & $?$ & (Kaiserling, 2001) \\
\hline Ulcerative colitis & \begin{tabular}{|l|} 
Descending colon \\
\end{tabular} & $?$ & (Kaiserling, 2001) \\
\hline \multicolumn{4}{|l|}{ Infectious Diseases } \\
\hline Chronic hepatitis C infection & Liver & $?$ & (Mosnier et al., 1993) \\
\hline \begin{tabular}{|l|} 
Helicobacter pylori or \\
Campylobacter gastritis
\end{tabular} & Stomach & Bacterial antigens & $\begin{array}{l}\text { (Genta, Hamner, \& Graham, 1993) } \\
\text { (Stolte \& Eidt, 1989) }\end{array}$ \\
\hline Chronic Lyme disease & \begin{tabular}{|l|}
$\begin{array}{l}\text { Synovial membranes of } \\
\text { joints }\end{array}$ \\
\end{tabular} & $?$ & (Ghosh et al., 2005) \\
\hline Oncocerciasis & \begin{tabular}{|l|l} 
Skin \\
\end{tabular} & $?$ & (Brattig et al., 2010) \\
\hline \multicolumn{4}{|l|}{ Cancers } \\
\hline $\begin{array}{l}\text { Lymphoma of MALT } \\
\text { associated with Sjögren's } \\
\text { Syndrome }\end{array}$ & Lymphoma & $?$ & (Bombardieri et al., 2007a) \\
\hline Ductal breast carcinoma & Breast tumour & $\begin{array}{l}\text { Epidermal growth factor } \\
\text { receptor family }\end{array}$ & $\begin{array}{l}\text { (Coronella et al., 2002) } \\
\text { (Nzula, Going, \& Stott, 2003a) } \\
\text { (Simsa } \text { et al., 2005) and section } 5 .\end{array}$ \\
\hline Medullary breast carcinoma & Breast tumour & Ganglioside & $\begin{array}{l}\text { (Coronella et al., 2001) } \\
\text { (Kotlan et al., 2005) }\end{array}$ \\
\hline
\end{tabular}

Table 1. Diseases in which ectopic germinal centres have been observed. 
It has now been shown by combined immunohistochemistry, identification of antigen specificity of B-cells and plasma cells in and around ectopic germinal centres, and sequence analysis of expressed, rearranged Ig V-genes and their somatic mutations, that germinal centre B-cells in the target tissues of several autoimmune diseases are undergoing clonal expansion, somatic hypermutation and affinity selection, in a similar manner to that seen in the germinal centres of secondary lymphoid organs (Table 1 and section 1.2). This has been demonstrated in Sjögren's syndrome, rheumatoid arthritis, psoriatic arthritis, myasthenia gravis, multiple sclerosis and also in breast cancer. In some of these cases, expression of RAG1 and 2 have been observed (Armengol et al., 2001), indicating that receptor revision also takes place in ectopic germinal centres and therefore the generation and attempted elimination of self-reactive B-cells. The signals involved in tertiary lymphoid organ neogenesis appear to be similar to those in development of secondary lymphoid organs, although the temporal and causal relationship between appearance of these structures in the target tissue and autoimmune pathology-related tissue damage is unclear. One scenario is that an initial event in the tissue, which could, in some cases, include microbial infection, leads to the release of molecules seen by the immune system as "danger signals" (Matzinger, 2007) thereby inducing infiltration of inflammatory cells and subsequent lymphoid neogenesis, causing further tissue damage with concomitant release of selfantigens, more danger signals and a vicious cycle, perpetuating a chronic autoimmune reaction. Alternatively, initial tissue damage may be caused by an autoimmune response commencing in the secondary lymphoid organs, with subsequent events following a similar course to that described above. Lymphotoxins $\alpha, \beta, a_{1} \beta_{2}$ and TNFa have been shown to be required for development of ectopic germinal centres. Growth-factor receptor-bound protein-2 (Grb2) has recently been shown to control orthotopic lymphoid follicle organisation and the germinal centre response by inducing production of lymphotoxin- $a$ via CXCR5 signalling (Jang et al., 2011). These molecules are secreted by infiltrating B and $\mathrm{T}_{\mathrm{h}} 1-$ cells and activated NK cells; on binding to their receptor on stromal cells they induce expression of adhesion molecules and secretion of chemokines which induce further lymphocyte infiltration and segregation into B-cell follicles, formation of a follicular dendritic cell network and T-cell areas. It has also recently been proposed that overexpression of costimulatory molecules on $\mathrm{T}_{\mathrm{fh}}$-cells may contribute to overcoming B-cell tolerance (Patakas et al., 2011). This may be a contributory factor in ectopic as well as orthotopic germinal centres. Primary B-cell follicles are rarely seen in autoimmune disease target tissues but this may be because chronic antigen stimulation has been in progress for a considerable time before biopsies are taken. For example, in type I diabetes mellitus there is evidence that the autoimmune response develops long before overt disease is diagnosed. Whether ectopic germinal centres are initiated by naïve or memory B-cells is unclear but recent evidence shows that at least some B-cell clones arise de novo from naïve B-cells (Sims et al., 2001; Nzula, Going, \& Stott, 2003b; Nzula, Going, \& Stott, 2003a).

The frequency of ectopic germinal centres varies markedly between autoimmune diseases; as one might expect, the highest incidence is in diseases where pathogenic autoantibodies are most strongly implicated. Thus, they have been identified in thyroid tissues of $100 \%$ of Hashimoto's thyroiditis patients and $54-63 \%$ of Graves' disease cases; in rheumatoid arthritis the figure is $25-50 \%$ but in Sjögren's syndrome it is only $17 \%$, although variations may to some extent reflect differences in the difficulty of finding the germinal centres. In Sjögren's syndrome, the source is usually biopsies of the small labial salivary glands of which there is a large number; as g.c.s are only present in some of the many small labial 
salivary glands, they may easily be overlooked. Tissues containing different types of cells respond in a variety of ways to inflammatory signals and this may also determine whether, and to what extent, lymphoid organ neogenesis occurs. The origin of follicular dendritic cells is unclear but it has been proposed that they develop from precursor cells already present in the tissue, either fibroblasts or fibroblast precursor cells (Park \& Choi, 2005). Alternatively, the precursor cells may be induced to migrate into the tissue by the same or similar chemokines as those attracting the B and T-lymphocytes. In several autoimmune diseases (Table 1) and animal models of autoimmune diseases (Astorri et al., 2010; Nacionales et al., 2009), it has been demonstrated that ectopic germinal centres are generating plasma cells secreting pathogenic autoantibodies and, almost certainly, memory B-cells bearing anti-self antigen receptors, implying that they aid the diversification of the autoantibody repertoire and contribute to the maintenance of immune pathology. In addition to autoantibody production, self-reactive B-cells generated in ectopic germinal centres may also contribute to autoimmune pathology by secretion of pro-inflammatory cytokines and activation of pathogenic T-cells by presentation of processed self-antigens. Bcells may contribute in this way to immune pathology in autoimmune diseases generally considered to be principally T-cell mediated, and may be one explanation for the efficacy of Rituximab therapy for rheumatoid arthritis.

\section{Methods}

\subsection{Identification and cellular composition of ectopic germinal centres}

The methods we used to identify ectopic germinal centres, characterise their cellular composition, analyse the rearranged Ig V-gene sequences expressed by germinal centre Bcells and identify their antibody specificity have been described in detail in previously published papers (Nzula, Going, \& Stott, 2003a; Sims et al., 2001). Briefly, sections were cut from snap frozen tissue biopsies and every tenth section stained for B-cells with anti-CD20. Sections containing germinal centre-like structures or B-cell aggregates were further characterised by staining for T-cells (anti-CD3, CD4, CD8), regulatory T-cells (anti-FoxP3), follicular dendritic cells (anti-FDC (DAKO) or anti-CD35), plasma cells (DAKO), macrophages (anti-CD68) and proliferating cells (anti-Ki67). Double immunofluorescent staining with the above cell subset-specific antibodies and Ki67 was used to identify dividing cells. Acetylcholine receptor-specific B-cells in germinal centres from the thymus of myasthenia gravis patients were identified by 125 I-a-bungarotoxin-labelled acetylcholine receptor and autoradiography (Shiono et al., 2003; Hill et al., 2008); other autoantibodyproducing cells were identified by immunofluorescence staining with the relevant antigen.

\subsection{Cloning and sequence analysis of rearranged lg V-genes}

Ectopic germinal centres and B-cell aggregates were excised by microdissection, digested with proteinase $\mathrm{K}$ and the released DNA used as a template for amplification of the rearranged Ig V-genes by nested PCR. Details of the method and the primers are described in Sims et al. (2001) and Nzula et al. (2003). Amplified DNA was purified by agarose gel electrophoresis, ligated into plasmid DNA and cloned in E. coli. Cloned plasmid DNA was purified and the Ig V-genes sequenced in both directions using primers complementary to sequences flanking the cloning site. The best matching germline $\mathrm{V}, \mathrm{D} \& \mathrm{~J}$ sequences were identified initially by comparison with the VBASE directory of human Ig V-genes and later, after VBASE ceased to be updated, using the Immunogenetics (IMGT) Database of Human 
Immunoglobulin Sequences (http://www.imgt.org/). Sequences were analysed using JOINSOLVER (http://joinsolver.niaid.nih.gov/) and IMGTV-QUEST. Silent and replacement somatic mutations were identified by comparison with the germline gene sequence; in early experiments the ratio of replacement to silent mutations was considered to be evidence of affinity selection if significantly higher than 3:1. To correct for the inherent bias towards replacement mutations in CDRs, we have more recently applied the method of Hershberg to determine whether affinity selection has occurred in B-cell clones from ectopic germinal centres (Hershberg et al., 2008). This method employs an algorithm that allows for the effects of microsequences in the complementarity determining regions (CDRs) and the bias towards transition mutations. Clonally related sets of rearranged V-genes were identified by their use of the same germline $\mathrm{V},(\mathrm{D})$ and $\mathrm{J}$ exons and shared junctional sequences. Genealogical trees were constructed by analysis of shared and unshared mutations using the parsimony method of phylogenetic analysis (PAUP, (Swofford, 1993)), enabling the assignment of sequences from parent and daughter cells that have been produced during clonal proliferation, thus providing clear evidence of the presence of clonally proliferating, somatically mutating B-cells within the germinal centre.

\subsection{Cloning antigen-specific autoantibodies from germinal centre B-cells by 'phage display}

In order to confirm the antigen specificity of B-cells generated in ectopic germinal centres, and to analyse in detail the relationship between their mutations and antigen specificity, we reconstituted the rearranged Ig V-genes as single chain $\mathrm{Fv}(\mathrm{scFv})$ or Fab antibodies by 'phage display. Single chain Fv antibodies comprise the heavy and light chain variable region domains linked by a short peptide. Although linked together by a short additional peptide sequence, the $\mathrm{V}_{\mathrm{H}}$ and $\mathrm{V}_{\mathrm{L}}$ domains are able to fold into their natural 3-dimensional conformation and pair correctly, as the antibody produced by a B-cell or plasma cell. They contain the antigen binding site, and therefore mimic the antigen specificity of the original antibodies from which they were derived. A caveat that must be born in mind is that the original $\mathrm{H}$ and $\mathrm{L}$ chain pairings are unknown, except when both genes are cloned from a single cell. The detailed methodology has been described elsewhere (Stott \& Sims, 2000; Matthews et al., 2002). Rearranged $V_{H}$ and $V_{L}$-genes amplified either from microdissected germinal centres or pooled V-genes from the same B-cell clone, were used to construct scFvs using a $\left(\mathrm{Gly}_{4} \mathrm{Ser}\right)_{3}$ linker DNA. The resulting scFv library, comprising a pool of randomly linked $\mathrm{V}_{\mathrm{H}}-\mathrm{V}_{\mathrm{L}}$ genes, was then inserted into the phagemids pCANTAB6 or pHEN2 continuously with the gene encoding the bacteriophage coat protein $\mathrm{P} 3$, and grown in E. coli in the presence of helper phage. The resulting scFv-P3 fusion protein was expressed on the surface of bacteriophage or as soluble $\mathrm{scFv}$ by transfection into a non-permissive, or permissive, strain of E. coli respectively. Alternatively, Fab libraries were constructed using whole light chain cDNA and DNA encoding the $\mathrm{V}_{\mathrm{H}}$ region and the first constant region domain of the heavy chain by similar techniques (Matthews et al., 2002). An advantage of amplifying directly from genomic DNA is that the distribution of cloned V-genes reflects the usage of those genes by B-cells and plasma cells more accurately than amplification from cDNA, which is biased towards plasma cells. The library of scFvs or Fabs attached to bacteriophage by the P3 'phage coat protein was then panned on plastic plates coated with either a whole extract of the target tissue, or purified recombinant antigen, to identify selfreactive antibodies. Bound 'phage were washed, eluted, re-grown in E. coli and panning 
repeated until the eluate had become enriched with a small number of 'phage clones. These were recloned and their $\mathrm{H} \& \mathrm{~L}$ chains sequenced and used to investigate the specificity and properties of their antigen-binding sites.

\subsection{Statistical analysis}

The method of Hershberg et al. (2008), described in section 2.2 above, was used to determine the significance of replacement mutations in rearranged Ig V-genes cloned from germinal centre B-cells, as evidence for affinity maturation of the antibodies expressed by them. The distribution of $\mathrm{V}_{\mathrm{H}}$ gene families and individual $\mathrm{V}, \mathrm{D}$ and $\mathrm{J}$ exons was assessed using twotailed $\chi^{2}$ analysis, corrected for multiple comparisons.

\section{The ectopic germinal centre response in myasthenia gravis}

\subsection{Pathology of myasthenia gravis}

Myasthenia gravis is an organ-specific autoimmune disease characterised by weakness of striated muscles and thymic hyperplasia (Vincent, 2002). Patients are generally divided into subgroups with early-onset (EOMG, pre-40 years) or late onset (LOMG, post-40 years) forms of the disease, or with thymoma in about $10 \%$ of patients. It is a classic autoantibodymediated autoimmune disease, caused by autoantibodies directed against the postsynaptic nicotinic acetylcholine receptor (AChR) at the neuromuscular junction. Many thymoma patients and some late onset patients also have serum antibodies against striated muscle antigens, interferon- $\alpha$ and IL-12. Loss of functional AChRs leads to muscle weakness, usually first evident in weakness of eye movement. This can progress to other striated muscles of the body, causing problems with breathing due to effects on the diaphragm, swallowing difficulties and paralysis. These effects can be life-threatening if untreated. Evidence that the effects are mediated by autoantibodies against the AChR include induction of similar symptoms by: their transfer from mother to baby in utero; passive transfer from patients to mice; immunisation of animals with AChR; and marked improvement of symptoms in patients after removal of circulating IgG antibodies by plasmapheresis. Several pathogenic mechanisms are involved (Vincent, 2002; Drachman, 1994): (i) Cross-linking of the receptor by autoantibodies causes loss of AChR by antigenic modulation, leading to internalisation and degradation of the receptors; (ii) The majority of anti-AChR antibodies are of the IgG1 and IgG3 subclasses, which are particularly efficient at complement activation, resulting in lysis and damage to the muscle membrane; (iii) Less commonly, some antibodies cause direct inhibition of the ion channel function of the AChR; (iv) Antibody-dependent cell-mediated cytotoxicity has also been implicated, although there is little direct evidence for this mechanism. The IgG autoantibodies can cross the placenta of pregnant mothers with myasthenia gravis by an active transport mechanism involving the neonatal Fc receptor, FcRn, resulting in transient symptoms of myasthenia gravis in the newborn infant. The symptoms gradually ameliorate as the maternal antibodies are catabolised and replaced by the infant's own antibodies. More rarely, the autoantibodies produced by multiparous mothers can induce severe, often fatal, developmental abnormalities, termed arthrogryposis multiplex congenita, due to paralysis of fetal muscles in utero (see section 3.4.5).

\subsection{Structure and epitopes of the acetylcholine receptor}

The AChR is a pentameric transmembrane glycoprotein found almost exclusively at the muscle endplate, comprising two a polypeptide subunits, one $\beta$, one $\delta$ and, in the adult, one 
$\varepsilon$ subunit; in the fetus there is also one $\gamma$ subunit, which is gradually replaced by an $\varepsilon$ from the third trimester onwards (Fig. 2) (Vincent, 2002). The five subunits are combined into a cylindrical structure with a central cation channel that is closed in the inactive conformation. There are two binding sites for acetylcholine, formed at the interfaces between one $\alpha$ and $\delta$ subunit and the second $\alpha$ and $\varepsilon$ or $\gamma$ subunits. Electrical impulses passing down the motor nerve trigger release of acetylcholine molecules at the nerve termini. When these bind to the two receptor binding sites, they cause the central cation channel to open and sodium ions to flood into the muscle resulting in local membrane depolarisation. When this reaches threshold the resulting action potential spreads across the muscle triggering it to contract. Loss of at least $50 \%$ of receptors is required to produce overt muscle weakness.

(a)

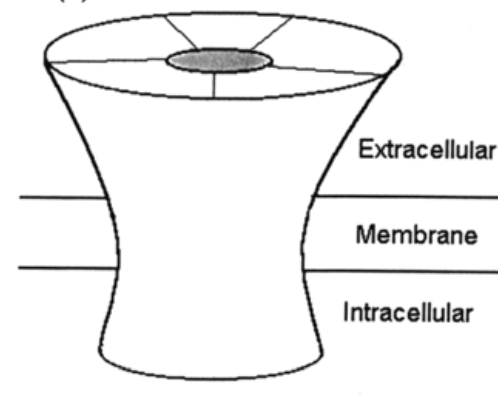

(c)

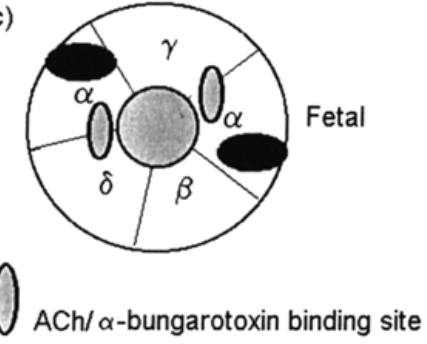

(b)
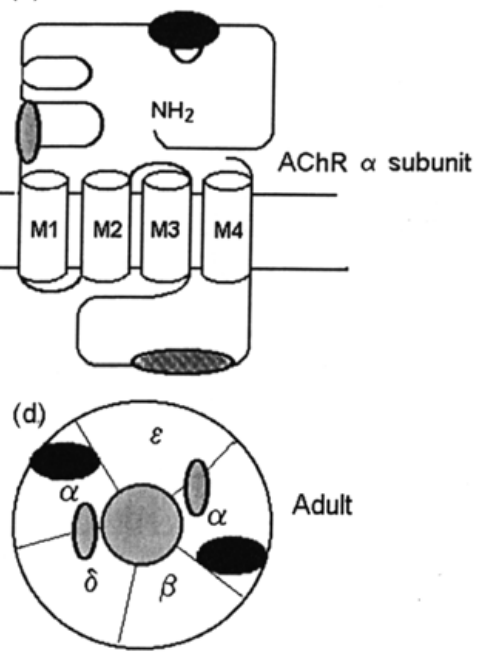

Adult

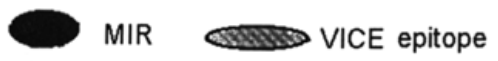

Fig. 2. Diagrammatic representation of the structure of the acetylcholine receptor:

(a) the complete pentameric molecule in the cell membrane; (b) the topology of the subunits, illustrated for the a subunit that contributes to the acetylcholine/a-bungarotoxin binding site, the main immunogenic region (MIR) and the very immunogenic cytoplasmic epitope (VICE); It is doubtful whether the latter plays any significant role in pathogenesis; (c and d) the fetal and adult subtypes of AChR. Reproduced with permission from (Vincent et al., 1997), Plenum Press.

Since the patients' autoantibodies are almost exclusively specific for the complex native conformation of the extracellular AChR subunit domains, and not short peptides or even whole subunit polypeptides, mapping of the autoantibody epitopes has proved to be difficult. The antibodies are mainly IgG1 or IgG3, of high avidity and heterogeneous in their sequences and fine specificity. Disease severity correlates poorly with autoantibody titre, suggesting that pathogenicity may depend upon precise epitope specificity. Many of the antibodies bind to a region of the extracellular domain of the a chain, the main immunogenic region or MIR. Its conformation is affected by the $\varepsilon \leftrightarrow \gamma$ interchange, as 
demonstrated by the observation that some antibodies bind better to the MIR of the fetal AChR than the adult form, even though the $\gamma$ and $\varepsilon$ subunits do not contribute directly to the MIR (Fostieri, Beeson, \& Tzartos, 2000). Titres of MIR antibodies vary considerably between patients and other antibodies may play an equally important role in some individuals. Some patients also produce autoantibodies against the acetylcholine binding sites (that also bind a-bungarotoxin); these are the blocking antibodies described above.

\subsection{Role of the thymus}

Early onset myasthenia gravis is associated with thymic hyperplasia characterized by secondary lymphoid organ-like structures in the medulla of $>90 \%$ of patients. These include T-cell areas containing AChR-specific helper T-cells and large numbers of germinal centres with clearly defined mantle, dark and light zones. Plasmablasts and plasma cells secreting autoantibodies against $\mathrm{AChR}$ are also detectable within and around the germinal centres (Hill et al., 2008; SHIONO et al., 2003). Approximately 20\% of germinal centres contain plasmablasts positive for antibodies against $\mathrm{AChR}$ and $\mathrm{AChR}$ is trapped on follicular dendritic cells in c.50\% of thymic germinal centres (SHIONO et al., 2003). Anti-AChRsecreting hybridomas and AChR-specific Fabs have been cloned from thymic B-cells and thymectomy results in a reduction in the serum anti-AChR titre and reduced clinical symptoms in some patients, although the benefits of thymectomy have never been rigorously proved (Cardona et al., 1994; Farrar et al., 1997; Graus et al., 1997). The relative contribution of the thymus to production of anti-AChR autoantibodies compared with the secondary lymphoid organs is unknown, but it appears to play a significant role. Therefore, using the methods described in section 2, we tested the hypothesis that thymic germinal centres are sites of ongoing autoimmune responses driven by autoantigen, i.e. sites of activated B-cells, clonally proliferating, somatically mutating their expressed Ig V-genes and undergoing affinity maturation, driven by the acetylcholine receptor.

\subsection{The thymic germinal centre response in myasthenia gravis \\ 3.4.1 Germinal centres in the thymus}

Thymi from 5 EOMG patients were examined by immunohistology. All 5 contained large numbers of germinal centres with typical mantle zones within the thymic medulla, histologically indistinguishable from germinal centres in human tonsil controls. The mantle zones contained densely packed $\mathrm{CD} 20^{+} \mathrm{B}$-cells surrounding the germinal centre B-cells (Fig. $3 \mathrm{~A})$. These were interspersed with a network of follicular dendritic cells extending throughout the dark and light zones (Fig. 3C) and a crescent of T-cells can be seen at the apex of the light zone (Fig. 3B). Proliferating B-cells were distributed throughout the germinal centre but in larger numbers within the dark zone (Fig. 3D). Autoradiography with 125I-a-bungarotoxin alone, which binds to AChR, diffusely labelled c.50\% of germinal centres and appeared to be associated with the follicular dendritic cell processes. No labelling was seen in human tonsils or thymi from two seronegative myasthenia patients and bungarotoxin binding was blocked by the cholinergic drug, carbamyl choline, which is structurally similar to $\mathrm{AChR}$, indicating that the follicular dendritic network contained membrane-bound antigen or immune complexes.

In contrast, ${ }^{125} \mathrm{I}$-a-bungarotoxin-labelled AChR bound to individual cells in $20 \%$ of germinal centres, including large numbers of moderately labelled centrocytes in the light zone, smaller numbers in the dark zone, and heavily labelled plasmablasts/plasma cells in and around the germinal centres (Fig. 3E \& F). 

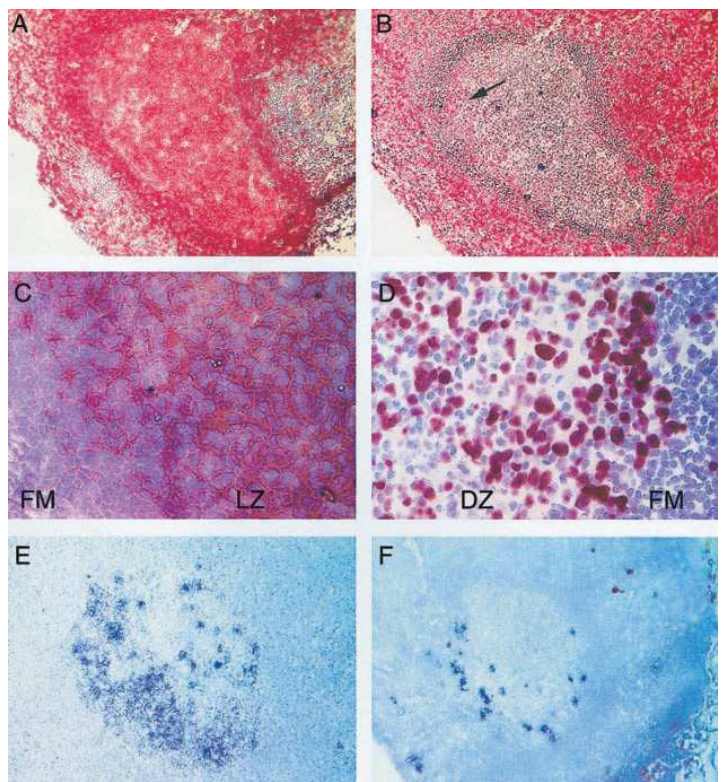

Fig. 3. Immunohistochemically stained serial sections through thymic germinal centres.

A \& B: Germinal centres stained (red) with anti-CD20 and anti-CD3 for B and T-cells respectively. The arrow (B) shows a crescent of T-cells in the light zone. C: A network of follicular dendritic cell processes is spread throughout the germinal centre, including both the light and dark zones. D: Germinal centre cells stained with an antibody against proliferating cell nuclear antigen, revealing dividing B-cells in both areas but more concentrated in the dark zone. E \& F: ${ }^{125 I-a-b u n g a r o t o x i n-l a b e l l e d ~ A C h R ~ r e v e a l s ~}$ individual AChR-specific plasmablasts/plasma cells in and around germinal centres (detected by autoradiography). Diffuse labelling in the light zone probably indicates binding of free ${ }^{125}$ I-abungarotoxin to AChR trapped on follicular dendritic cells (see text). Reproduced from Sims et al (2001).

\subsubsection{Ig V-gene expression by thymic germinal centre B-cells}

In order to determine whether thymic germinal centre B-cells are subjected to antigendriven clonal proliferation, somatic hypermutation and affinity selection, as seen in the orthotopic germinal centres of secondary lymphoid organs, we cloned and sequenced rearranged Ig heavy chain $\mathrm{V}$-genes from multiple sections through four thymic germinal centres (A - D) and the follicular mantle surrounding one of them (A). 216 rearranged $\mathrm{V}_{\mathrm{H}^{-}}$ genes, derived from 61 independently rearranged, functional sequences, were obtained from the four germinal centres and $46 \mathrm{~V}_{\mathrm{H}}$-genes from the follicular mantle were derived from 24 functional $\mathrm{V}_{\mathrm{H}^{-}}$genes. Since the PCR error rate in control experiments was estimated to be

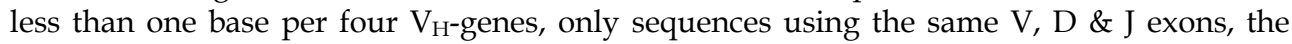
same junctional sequences and a minimum of one base difference per gene, were accepted as mutated members of a clonally related set of B-cells. This conservative assessment almost certainly discards some B-cell clones with low frequencies of somatic mutation and therefore underestimates the true B-cell diversity. When calculating the number of $\mathrm{V}_{\mathrm{H}}$-genes used, members of the same B-cell clone were counted only once. However, this reflects the number of individual B-cell clones and non-dividing B-cells rather than the total number of B-cells using a particular gene. 
The distribution of $\mathrm{V}_{\mathrm{H}^{-}}$-gene families was similar in the follicular mantle and all four germinal centres, with predominant use of members of the $\mathrm{V}_{\mathrm{H}} 3$ gene family compared with the number of germline $\mathrm{V}_{\mathrm{H}^{-}}$genes in this family (Fig. $4 \mathrm{~A}$ ). However, since this gene family is also predominantly used by the peripheral blood B-cells of healthy individuals, it was not considered to be significant. No $\mathrm{V}_{\mathrm{H}} 6, \mathrm{~V}_{\mathrm{H}} 7$ or $\mathrm{J}_{\mathrm{H}} 2$ genes were isolated and $\mathrm{J}_{\mathrm{H}} 1$ was underused, but the rarely used $V_{\mathrm{H}} 5-51$ gene and the $\mathrm{J}_{\mathrm{H}} 4$ exon (Fig. 4B) were over-represented, both being used by rearranged $\mathrm{V}$-genes from three different germinal centres in combination with different $\mathrm{D}$ exons $\left(\mathrm{D}_{\mathrm{H}} 2-2, \mathrm{D}_{\mathrm{H}} 5-12\right.$ and $\left.\mathrm{D}_{\mathrm{H}^{-}}-6-19\right)$. In many cases the $\mathrm{D}$ exon could not be identified due to junctional diversity and removal of bases during recombination. Of those that could be identified, $\mathrm{D}_{\mathrm{H}} 3$ and $\mathrm{D}_{\mathrm{H}} 6$ were the most commonly used. These data strongly imply selection for B-cells expressing antigen receptors using particular combinations of $\mathrm{V}$, $\mathrm{D}$ and J segments, despite the heterogeneity of the germinal centre B-cells. This would be even more apparent if individual members of the same B-cell clone were counted separately.
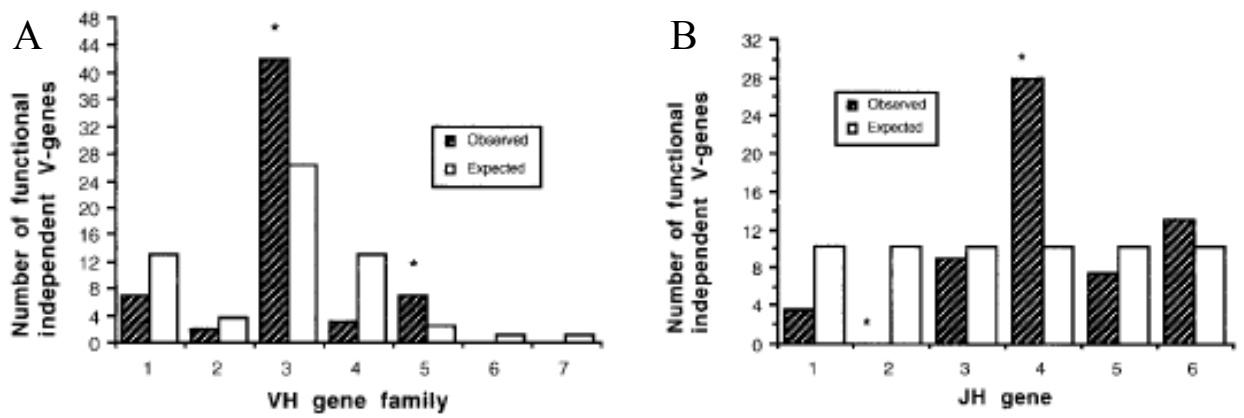

Fig. 4. Frequency of usage of $\mathrm{V}_{\mathrm{H}}$ and $\mathrm{J}_{\mathrm{H}}$ germline genes by thymic germinal centre B-cells.

A: The frequency of $\mathrm{VH}$ gene family usage in all germinal centres analysed differs significantly from predictions from the number of members of each family in the germline. Members of clonally related sets were only counted once. B: The frequency of individual $\mathrm{JH}$ exon usage in all germinal centres analysed differs significantly from the number of $\mathrm{JH}$ exons in the germline $\left({ }^{*} \mathrm{p}<0.01\right)$. Reproduced from Sims et al (2001).

\subsubsection{Somatic hypermutation and clonal proliferation of B-cells in thymic germinal centres}

All the germinal centres and the follicular mantle contained B-cells expressing both mutated and unmutated Ig V-genes, the latter presumably coming from naïve B-cells. The majority of $\mathrm{V}$-genes from the germinal centres and the follicular mantle were mutated, with considerable variation in the number of mutations, ranging from $0-52$. Some of the rearranged V-genes in clonally related sets had high ratios of replacement to silent mutations from 4.7:1 to 7.0:1 in the CDRs, which form the antigen-binding site, suggesting affinity selection of mutated antigen receptors is taking place in the germinal centre. Some other sequences had low numbers of replacement mutations, suggesting selection against replacement mutations, as also found by (Zuckerman et al., 2010). 18 different sets of functionally rearranged $V_{H^{-}}$genes included two or more related sequences sharing the same $\mathrm{V}, \mathrm{D}$ and $\mathrm{J}$ segments and junctional sequences but with significantly more than one mutation per V-gene and, in three cases, they were cloned in separate amplifications from different sections through the same germinal centre and therefore could only be from different B-cells. 

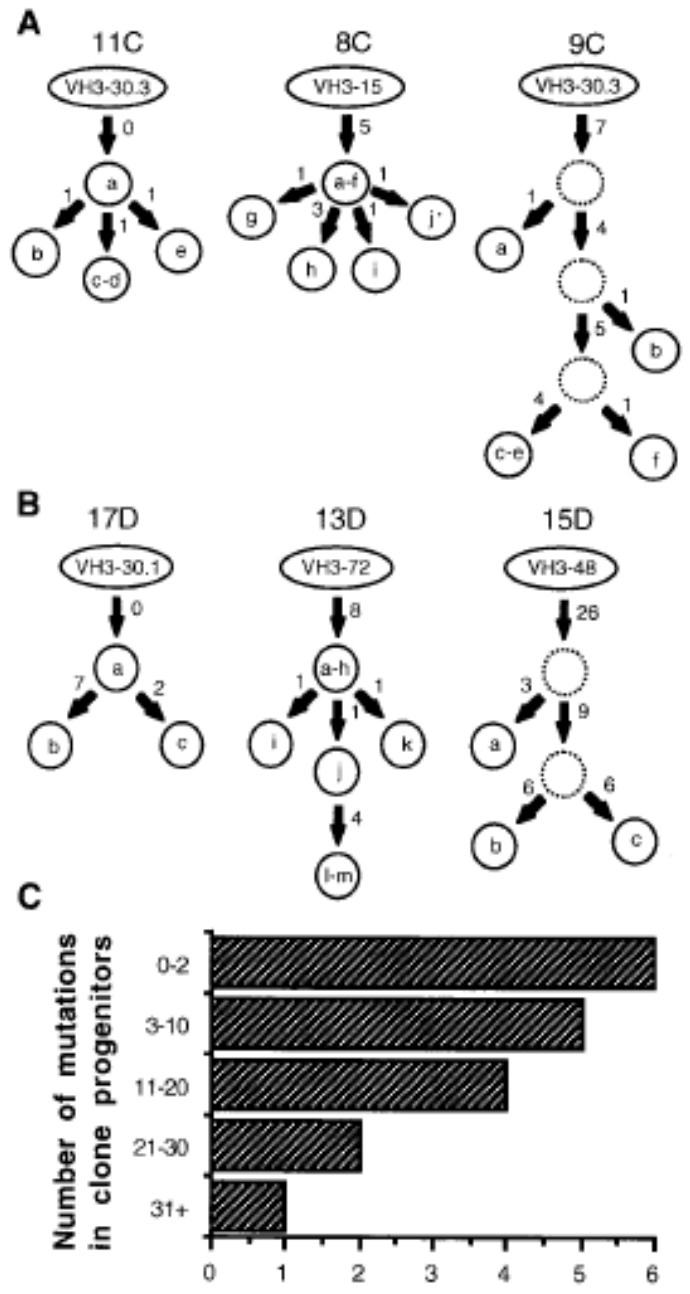

Number of B-cell clones

Fig. 5. Examples of clonally related sets of rearranged $V_{H}$ genes isolated from thymic germinal centres $\mathrm{C}$ and $\mathrm{D}$.

The genealogical trees were constructed using the most parsimonious parent-daughter cell relationships of clonally related sets of sequences (section 2.2). The best matching germline gene is depicted as an ellipse. Letters in the circles refer to individual sequences from the same clonally related set. Deduced intermediates are shown as dotted circles. Numbers at the side of the arrows indicate the minimum number of mutations required to generate a daughter cell from the immediate parental cell. The results show that the B-cells from which they were derived are undergoing antigen-driven clonal proliferation and somatic hypermutation from both naïve and memory B-cell precursors. A: B-cell clones from germinal centre C; B: B-cell clones from germinal centre D; C: Frequency of mutations in the $\mathrm{V}_{\mathrm{H}}$ genes expressed by the most probable progenitor cells of all 18 B-cell clones analysed. Reproduced from Sims et al. (2001). 
These related sets of V-genes were therefore derived from members of the same proliferating B-cell clone, showing that antigen-driven B-cell proliferation and somatic hypermutation are taking place within the thymic germinal centres. All of the isolated B-cell clones were small, containing a maximum of five members.

We do not know the total number of clones proliferating within a single germinal centre. We examined every tenth section but may have missed small B-cell clones, so there are likely to be more than we detected. Genealogical trees of related sets of V-genes were constructed by the most parsimonious relationship on the basis of shared and unshared mutations (section 2.5). Six of the 18 clones isolated from two germinal centres containing AChR-specific B-cells were derived from unmutated precursors, i.e. naïve B-cells, whereas the $\mathrm{V}_{\mathrm{H}^{-}}$genes of the earliest founder cells isolated from the other 12 clones contained from 5 to $>30$ mutations. Examples of six of these clones are shown in Fig. 5. Although we cannot rule out the possibility that some of these clones were also derived from unidentified naïve B-cells, it is most probable that the majority were generated from founder memory B-cells. Thus, both memory and naïve B-cells have been stimulated by antigen and are proliferating and mutating their antigen receptors within thymic germinal centres of myasthenia patients.

\subsubsection{Evidence for selection of AChR-specific B-cell clones in thymic germinal centres} Three B-cell clones from 3 different AChR positive germinal centres expressed the rarely used $V_{H} 5-51$ genes. Furthermore, these three independent sets of V-genes exhibited the same amino acid replacements at three positions. Comparison of our V-gene sequences with those of heavy chains from known AChR-specific hybridomas and Fabs revealed some common features. Germline genes used by four of our B-cell clones also encode anti-AChR antibodies cloned from other EOMG patients, and several of the amino acid substitutions in CDR1 and CDR2 from two B-cell clones were also present in an anti-AChR Fab (Sims et al., 2001; Matthews et al., 2002). It is therefore unlikely that these mutations occurred by chance, suggesting that a common selection process for mutants with high affinity for the AChR is in operation.

\subsubsection{Evidence for immunisation by the fetal form of acetylcholine receptor}

Babies born to mothers with myasthenia gravis can develop transient symptoms due to transplacental transfer of the maternal autoantibodies and, in rare cases, they have severe developmental abnormalities, arthrogryposis multiplex congenita (AMC), caused by maternal anti-AChR antibodies that inhibit the ion channel function of the fetal AChR, causing paralysis during fetal development in utero, whereas the adult form of the mother's AChR is relatively unaffected. Fetal AChR-specific antibodies are particularly prevalent in women who have had babies, suggesting that they may be induced by the fetus.

In order to determine the specificity and clonal origins of fetal AChR-specific autoantibodies, combinatorial Fab libraries were constructed from cDNA prepared from thymic cells of two mothers (M2 and M6) of AMC babies. 25 Fab clones were isolated and two clonally related sets were examined in greater detail. All Fabs bound specifically to the $\gamma$ subunit of fetal $A C h R$, except one that recognised the $\beta$ subunit also present in the adult receptor. Sequencing of the fetal-specific Fabs revealed clearly restricted usage of $\mathrm{V}_{\mathrm{H}}, \mathrm{J}_{\mathrm{H}}, \mathrm{VK}_{\mathrm{K}}$ $\& \mathrm{~J}_{\mathrm{K}}$ gene segments and convergent coding mutations. All the Fabs from AMC mother M2 
used the $\mathrm{V}_{\mathrm{H}} 3-07$ gene recombined with $\mathrm{J}_{\mathrm{H}} 6 \mathrm{~b}$ and an unidentified $\mathrm{D}$ exon in combination with various $V_{K}$ genes, suggesting that the heavy chain is the major contributor to AChR binding, at least in this case. The $\mathrm{V}_{\mathrm{H}} 3-07$ segments were mutated and clonally related. Most of the Fabs from AMC mother M6 used the same combination of mutated $\mathrm{V}_{\mathrm{H}} 3-21$ and $\mathrm{J}_{\mathrm{H}} 5 \mathrm{~b}$, with an unidentified D exon, plus a $\mathrm{VK} 02-12 / \mathrm{J}_{\mathrm{K}} 4$ light chain, which was also used in two of the Fabs from M2. In this case, both the $\mathrm{V}_{\mathrm{H}} 3-21$ and $\mathrm{V}_{\mathrm{k}} 02-12$ sets of sequences were clonally related, suggesting that they may both be derived from the same B-cell clone. The clonally related sequences from both sets of Fabs from M2 and M6 contained many shared and unshared coding mutations. The apparent founder member of each set of sequences had a large number of base differences from the best matching germline V-gene, suggesting that the clones were derived from mutated memory B-cells (Fig. 6).
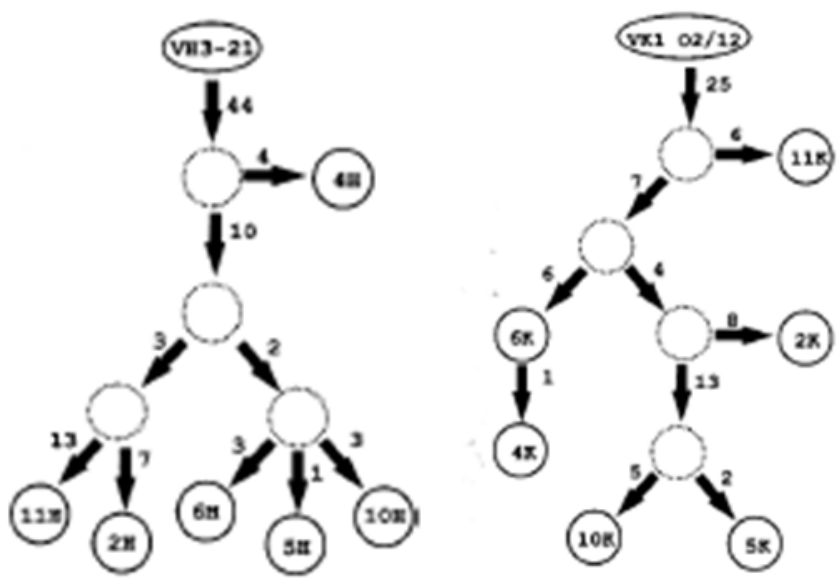

Fig. 6. Clonally related sets of rearranged $V_{H} \& V_{\kappa}$ genes encoding AChR-binding Fabs cloned from thymic cells from AMC mother M6.

The heavy and light chains were from the same set of Fabs. Genealogical trees were constructed and mutations numbered as described in the legend to figure 5. Fab names are shown in the circles, $\mathrm{H}$ referring to the heavy chain and $\mathrm{K}$ referring to the $\mathrm{K}$ light chain. Dotted circles represent hypothetical intermediates. Numbers at the side of arrows show the minimum number of mutations required to generate a daughter cell from its immediate parent. Reproduced from Matthews et al. (2002).

Several sequences from both clonally related sets of Fabs had many more replacement mutations than expected by chance, indicating affinity selection. There was also clear evidence of convergent mutations. Many independently rearranged sequences from both patients shared consensus mutations. All the Fabs using $\mathrm{V}_{\mathrm{H}} 3$ genes contained the same $31 \mathrm{~S} \rightarrow \mathrm{T}$ mutation and most of the VK02-12 genes contained a 22SRASET28 motif in CDR1. A search of the GenBank database of all human Ig sequences found only two other $\mathrm{K}$ chains containing this motif, suggesting that it is important in determining the specificity of the anti-AChR autoantibodies. 


\subsection{Conclusions}

Since the EOMG thymus contains many typical germinal centres surrounded by mantle zones, including clones of proliferating, AChR-specific B-cells, it is clearly a site of autoantibody diversification. The B-cells are undergoing somatic hypermutation and affinity selection by cognate binding to $\mathrm{AChR}$ bound to the membrane processes of follicular dendritic cells, which form a network surrounding B and T-cells in the germinal centres. Bcells expressing high affinity, AChR-specific antigen receptors receive rescue signals from follicular dendritic and helper T-cells inducing them to differentiate into antibody-secreting plasmablasts and plasma cells that migrate out of the follicles and leave the thymus to enter the circulation, in a classical germinal centre type response. The numerous mutations seen in some V-gene sequences suggests that Ig class-switched memory B-cells are also generated and either leave the thymus, or some may recirculate within the germinal centre, undergoing further rounds of somatic hypermutation and affinity selection, consistent with the observations of others that recirculation of centrocytes between the light and dark zones occurs in orthotopic germinal centres. Several of the B-cell clones we identified were derived from highly mutated precursors, which supports this hypothesis. The autoantibodies produced by mothers of AMC babies included antibodies specific for the fetal form of the $\mathrm{AChR}$, directed against the $\gamma$ subunit.

The reason why large numbers of germinal centres producing AChR-specific B-cells and plasma cells develop in the thymi of myasthenia gravis patients is unclear, but it is possible that the rare thymic myoid cells may be involved. The induction of fetal AChRspecific antibodies in parous women suggests, at least in some cases, that expression of the fetal AChR on thymic epithelial and myoid cells may initiate an immune response, for which the patient's immune system has not been tolerised. Furthermore, generation of thymic germinal centres may be induced by a pre-existing proinflammatory cytokine environment, including IFNY and TNFa. These molecules have been shown to upregulate expression of AChR subunits in thymic epithelial cells and on the membranes of myoid cells (Poea-Guyon et al., 2005). The chemokines CXCL13 AND CCL21 are produced by endothelial cells of the afferent lymphatic vessels in the thymus, attracting activated $\mathrm{T}$ and B-cells, including naïve B-cells, suggesting that this is the mechanism of induction of thymic germinal centres (Berrih-Aknin et al., 2009; Le Panse et al., 2006; Meraouna et al., 2006; Le Panse et al., 2010).

We therefore propose a two step process for initiation of the autoimmune response in myasthenia gravis (SHIONO et al., 2003). In step 1, there is hyperplasia of thymic epithelial cells expressing linear AChR epitopes, including the a and $\varepsilon$ subunits, in the context of the MHC Class II antigen HLA-DR52a, a susceptibility factor for EOMG patients. Whereas these peptides would normally induce tolerance, an imbalance in regulatory factors and expression of costimulatory molecules results in activation of thymic $\mathrm{T}_{\mathrm{h}}$-cells against $\mathrm{AChR}$ epitopes. In step 2, the $\mathrm{T}_{\mathrm{h}}$-cells induce an early B-cell response against the linear peptides and some of the resulting antibodies cross-react with conformational epitopes of the native AChR expressed on the thymic myoid cells, leading to myoid cell damage, release of AChR/antibody immune complexes, danger signals, and recruitment of professional antigen presenting cells. These stimulate an enhanced B-cell response accompanied by formation of germinal centres with production of high affinity, class switched, pathogenic autoantibodies. Although some aspects of this hypothesis are conjectural, they are also testable. 


\section{Tissue-infiltrating B-cells in inflammatory myopathies}

\subsection{Introduction}

The inflammatory myopathies (IM), collectively called myositis, are classified into three principal subsets, Dermatomyositis (DM), Polymyositis (PM) and Inclusion Body Myositis (IBM) (Bohan \& Peter, 1975a; Bohan \& Peter, 1975b; Dalakas \& Hohlfeld, 2003). Each of these disorders is characterised by moderate to severe muscle weakness and muscle fatigue with inflammatory mononuclear cell infiltration within the muscle, but each disorder has distinct clinical and pathological features. IM can be associated with various autoimmune and connective tissue disorders as well as malignancies, the latter being associated with up to $45 \%$ of adult DM patients.

$\mathrm{DM}$, the most common of the inflammatory myopathies, is a multi-organ disease not only affecting skeletal muscle but, often, the skin as well as other tissues and is more commonly found in women than men; it also accounts for up to c.85\% of all juvenile IM (Rider, 2007). $\mathrm{DM}$ is characterised by a heliotrope rash on the upper eyelid, face or upper trunk accompanying, or more commonly preceding, proximal muscle weakness. Muscle inflammation is predominantly perivascular and/or perimysial or in the interfascicular septae and around, rather than within, the muscle fascicles. Perivascular atrophy is a characteristic feature of DM patients, often in groups at the periphery of the fascicle. In DM, muscle lymphocytic infiltrates consist largely of B-cells and CD4 ${ }^{+}$T-cells (Arahata \& Engel, 1984; Engel \& Arahata, 1984) suggesting that DM may be a humorally mediated immune response.

PM and IBM, though separate disorders, are both characterised by scattered necrotic and regenerating muscle fibres and endomysial inflammation with invasion and destruction of non-necrotic muscle fibres. PM generally becomes evident in adulthood and is best defined as a subacute myopathy that evolves over weeks to months and presents with symmetrical weakness of the proximal muscles. Its clinical onset is hard to define with no early recognition signs such as the rash observed in DM. PM is uncommon as a stand-alone disorder and more commonly associates with other autoimmune and connective tissue disorders.

Onset of IBM is usually after the age of 50 and occurs more frequently in men. Muscle weakness can be both proximal and distal and is often asymmetrical. Despite similarities with PM, distinctive features of IBM include: rimmed vacuoles; groups of atrophic fibres; increased lymphocytic invasion of non-necrotic fibres; less frequent myofibre necrosis; and a more slowly progressing clinical course with patients being unresponsive to treatment. In both disorders, inflammatory infiltrates typically consist of $\mathrm{CD}^{+} \mathrm{T}$-cells and macrophages (Arahata \& Engel, 1984; Engel \& Arahata, 1984) which invade MHC Class 1 antigenexpressing muscle fibres, a feature absent in normal muscle tissue, leading to fibre necrosis. The muscle fibre invading CD8 ${ }^{+}$T-cells can be clonally expanded in both PM and IBM (Dalakas, 2004; Fyhr et al., 1997; Hofbauer et al., 2003; Mantegazza et al., 1993; Seitz et al., 2006), which persists over time (Amemiya, Granger, \& Dalakas, 2000).

\subsubsection{Autoantibodies associated with myositis}

As with most autoimmune disorders, different autoantibody specificities have been described in DM and PM; autoantibodies are generally absent from IBM although they have been detected in a small number of cases (Dalakas et al., 1997). They can either be myositisspecific (MSAs) or myositis-associated autoantibodies (MAAs), which can also be associated 
with other autoimmune diseases. Most bind to protein or ribonucleoprotein complexes involved in protein synthesis, translocation or elongation; MAA target antigens are primarily located in the nucleoplasm or nucleolus. The most prevalent MSAs are directed against amino-acyl-tRNA-synthetases (ARS), and are associated with a distinctive clinical phenotype, anti-synthetase syndrome, characterised by myositis, Raynaud's phenomenon and interstitial lung disease, with a higher mortality. Anti-Jo-1 (anti-histidyl-tRNA synthetase) antibodies are the most prevalent in myositis patients (20-30\% of patients), while the other anti-ARS antibodies are only present in 1-3\% of IM patients, and are a diagnostic and prognostic marker for disease severity (Mielnik et al., 2006; Zampieri et al., 2005).

\subsubsection{Muscle-infiltrating B-cells in myositis}

As described above B-cells have been found to be prominent within the muscle infiltrating cell populations of DM patients and are rarely found, or absent, in the inflamed muscle of PM and IBM patients. CD138 ${ }^{+}$plasma cells have been identified within the infiltrating populations, predominantly in the endomysial areas of muscle tissue of PM and IBM patients (Greenberg et al., 2002; Greenberg et al., 2005). This was confirmed by sequence analysis of immunoglobulin V-genes expressed by laser dissected cells as well as microarray studies which showed an abundance of immunoglobulin transcripts.

The role for B-cells and plasma cells in IM is still currently unresolved, with continuing studies providing further insight into the immune mechanisms. The identification of muscle infiltrating B-cells, plasma cells and autoantibodies suggests that these diseases may be at least partly driven by a loss of B-cell tolerance and, in the case of PM and IBM patients, not solely by the oligoclonal expansion of T-cells. We therefore investigated whether there is clonal expansion of infiltrating, autoantibody producing B-cells in situ in IM.

\subsection{The muscle infiltrating $B-c e l l$ response in myositis}

\subsubsection{The cellular composition of infiltrating lymphoid cells in myositis}

To determine whether specific, antigen-driven, B-cell adaptive immune responses were occurring in situ, we used the methods described in section 2 to study the cellular composition of muscle infiltrating cells in twelve different muscle samples (2 DM, 9 PM, 1 IBM); we also examined their Ig V-gene repertoire and the processes of somatic hypermutation and clonal diversification of the rearranged V-genes. In contrast with other autoimmune diseases (see above), no classical ectopic germinal centre structures were observed within the inflamed muscle; instead, muscle-infiltrating cells were present in cellular aggregations which varied from loose to dense in the appropriate perivascular/perimysial or endomysial locations, as in previous studies. B-cells were a significant component of the inflammatory infiltrate in all samples examined for all three myositis subsets, either as CD20+ B-cells or differentiated plasma cells (Figure 7A-D), although the most significant infiltration of CD20+ B-cells was observed within the muscles of the two DM patients. FDCs were rare, and were seen only in one IBM and three PM samples, and not at all in DM. In addition to these cell phenotypes, $\mathrm{CD}^{+}, \mathrm{CD}^{+}, \mathrm{CD} 8^{+}$, $\mathrm{CD}^{+} 8^{+}$and $\mathrm{FoxP}^{+}$cells were also present. Double immunofluorescence staining of cell phenotypes with the proliferating cell marker Ki67 identified proliferating cells within the infiltrating population. In addition to $\mathrm{CD} 20^{+} \mathrm{B}$-cells (Figure 7E \& F), proliferating $\mathrm{CD}^{+}$, $\mathrm{CD}^{+}, \mathrm{CD}^{+}$and $\mathrm{CD}^{+} 8^{+}$cells were observed, as well as FoxP3 ${ }^{+}$cells in one DM patient. 


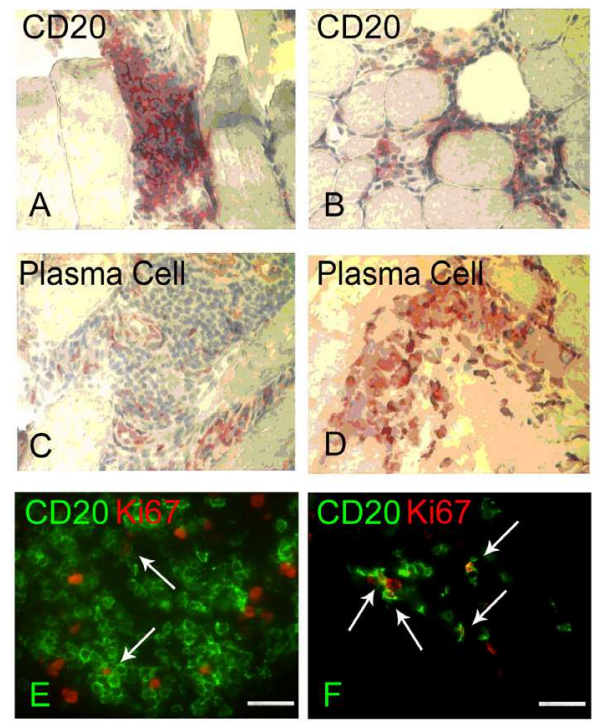

Fig. 7. Immunohistochemical staining of antigen-specific muscle-infiltrating B-cells and plasma cells.

A - D: Infiltrating B-cells and plasma cells (red) within inflamed muscle; E \& F: Proliferating B-cells (CD20+ B-cells - Fluorescein-Avidin D (green), Ki67+ - Texas Red-Avidin D (red)). Slides A, B, C \& E are from 2 DM patients; D \& F are from a PM patient. Original magnification for images A - D: 400x; E \& F: 630x. Scale Bar (E \& F) represents $15 \mu \mathrm{m}$. Arrows indicate double positive staining.

\subsubsection{The Ig V-gene repertoire and clonally proliferating, muscle-infiltrating B-cells}

Analysis of the repertoire of rearranged Ig V-genes expressed by infiltrating B-cells and plasma cells revealed significant biases for and against individual gene segments and families relative to the normal peripheral blood B-cell and the germline gene repertoires. Vgene usage varied between patients and myositis subsets and, in a few instances, differed significantly between the DM and PM subsets. Interestingly, naïve or unmutated B-cells (0-2 mutations per $\mathrm{V}_{\mathrm{H}}$ gene) constituted almost $50 \%$ of the B-cells in DM, but $<10 \%$ in PM, where a large proportion of sequences was highly mutated (c. $30 \%>20$ mutations). As expected, mutations were prevalent within CDRs 1 \& 2 . A total of nine clonally related sequences was found in five of the IM patients studied; 2 DM and 3 PM patients, each with up to four different clones comprising between two and ten clonal variants (Figure 8). These clonally related sequences provide evidence for specific, antigen-driven B-cell immune responses within the inflamed muscle. However, using the method of Hershberg et al. (2008), we found no evidence of positive selection in the CDRs of clonally related sequences, nor in any sequences isolated from the DM patients, and only in a small percentage from the PM patients. Finally, using biotinylated recombinant antigens, we identified antigen-specific $B$ and plasma cells in infiltrates from the five out of twelve patients whose autoantibody specificities were known, including Jo-1 (Figure 9).

Parallel studies (Bradshaw et al., 2007) also demonstrated B-cell responses in muscle of 3 DM, 2 PM and 7 IBM patients but very few $\mathrm{CD}^{+} 9^{+}$or $\mathrm{CD} 20^{+}$cells were observed, the 
majority of B-lineage cells being CD138+ plasma cells that had class switched to either IgG or IgA. Clonally related sequences were isolated from whole muscle sections from ten of the twelve myositis patients, with up to four different clonal sets isolated from each muscle sample. Further studies also support the absence of classical ectopic germinal centre structures and the clonal expansion and maturation of B-cells within inflamed muscle (Salajegheh et al., 2010). Collectively this and our work strongly suggest the participation of antigen-specific B-cell immune responses within the muscle.

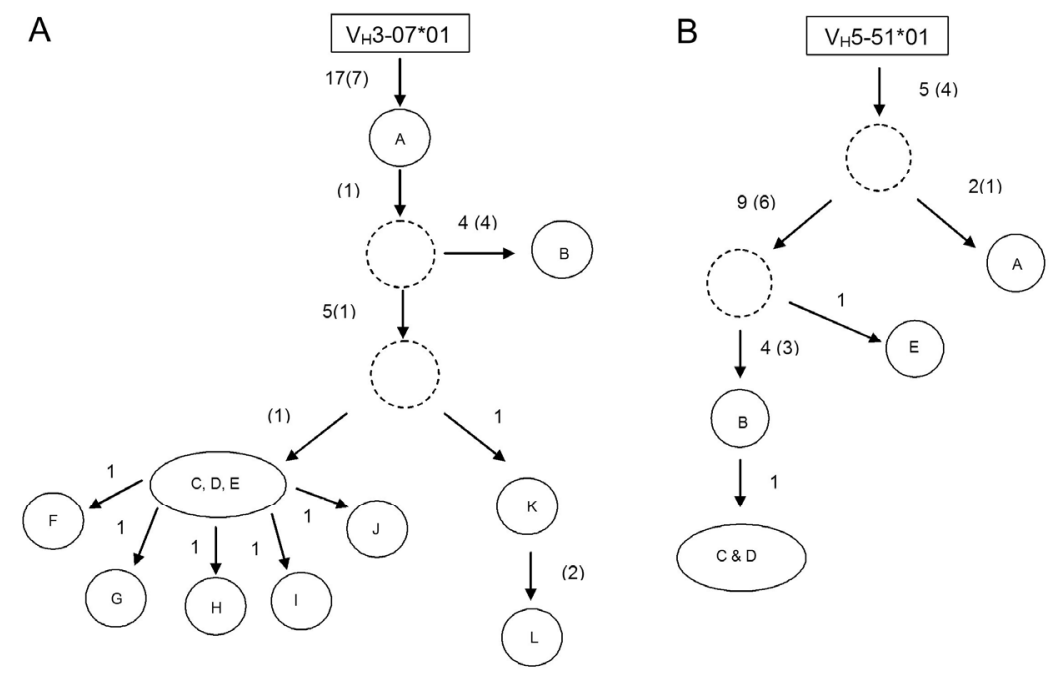

Fig. 8. Oligoclonal expansion of B-cells and plasma cells in inflammatory myopathies

Representative examples of clonal genealogical trees constructed from sequences isolated from muscleinfiltrating B-cells and plasma cells in individual patients, representing the minimum number of cell divisions required to generate each daughter cell. Clone A from a DM patient; clone B from a PM patient. The letters in the circles refer to individual sequences isolated from each B-cell clone. Genealogical trees were constructed and mutations numbered as described in the legend to Figure 5. Bracketed figures representing additional silent mutations. Dashed circles represent hypothetical intermediates whose sequences were not isolated from the muscle-infiltrating population.
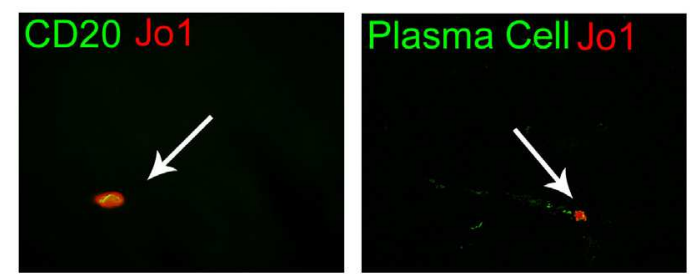

Fig. 9. Infiltrating antigen-specific B-cells and plasma cells in inflammatory myopathies

CD20+ B-cells and antigen-specific cells were visualised by Fluorescein-Avidin D (green) and Texas Red-Avidin D (red) respectively. Original magnification was 630X. Arrows identify antigen-specific cells within the muscle-infiltrating population of polymyositis patients. 


\subsection{Conclusions}

As previously described in other autoimmune diseases, a role for B-cells in IM is implied by the clinical improvement in patients administered Rituximab ${ }^{\circledR}$ therapy, including improvements in muscle strength. Some patients relapsed as their B-cell pools repopulated and depletion of autoantibody titres was variable (Chung, Genovese, \& Fiorentino, 2007; Cooper et al., 2007; Levine, 2005). The potential of B-cells as therapeutic targets is further supported by the elevations in serum levels and gene expression of B-cell activating factor (BAFF) in IM patients, a cytokine crucial for B-cell maturation and survival, which is also thought to play a role in autoantibody production (Krystufkova et al., 2008; Salajegheh et al., 2010).

Despite all the evidence described here implicating B-cells and loss of B-cell tolerance in the IM, numerous questions still remain to be resolved, including identification of the stimulating antigens and epitopes, sequence characteristics and pathogenicity of highaffinity, antigen-specific antibodies produced in situ, and the factors regulating and controlling these autoimmune reactions. The resolution of these questions will enhance our understanding of the immune pathology of IM and facilitate the diagnosis, treatment and management of these diseases.

\section{The ectopic germinal centre response in breast cancer}

In autoimmune diseases there is a failure of immunological tolerance resulting in an immune response to self-antigens, causing pathological damage to the target organ and tissues, the nature of the target tissue depending on the specificity of the response. In malignancy the immune response, if it occurs, is similar in that it is essentially directed against self, i.e. tumour-associated, antigens. These antigens may be mutated, altered by metabolic processes, or merely aberrantly or over-expressed on the tumour. The problem, however, is converse to autoimmune disease in that, whereas in autoimmune disease the aim is to suppress the immune response, preferably specifically against the target organ, in cancer the hope is that it will be possible to boost the immune response which is often too weak to overcome the rapidly growing tumour.

Several autoimmune disorders sometimes associate with certain tumours, most often small cell lung cancer, breast or ovarian carcinomas, ovarian teratomas, neuroblastomas and lymphomas (with Sjögren's syndrome), reviewed by Lang \& Vincent and Rosenfeld et al. (Lang \& Vincent, 2009; Rosenfeld \& Dalmau, 2010). In the examples studied, the target autoantigen(s) are expressed on the tumour which seems to autoimmunise against them. Indeed, if the tumour is removed, autoantibody levels often decline (Chalk et al., 1990). In many syndromes, the autoimmune disorder serves as a valuable early warning of the associated tumour, and may even slow its growth (Maddison \& Lang, 2008).

\subsection{Pathology of breast cancer}

Breast cancer is the second most common malignancy in women, accounting for $31 \%$ of all types of cancer, with a lifetime incidence in the U.K. of 1/8 in women and c.1/1000 in men. Despite advances in screening, diagnosis and therapy, 12,000 women die of breast cancer each year in the U.K. and the global incidence in females is $23 \%$, but there are marked variations between different regions, it being the highest in Western Europe, Australia, New Zealand and North America. The incidence is relatively low in Asian and African countries (figures from Cancer Research UK). There are several different histopathological types of 
breast cancer, of which the major types are the ductal and lobular carcinomas, either of which can be in situ or invasive, the in situ type being considered a possible precursor of invasive carcinoma. Ductal and lobular carcinomas in situ are confined to the mammary ducts and lobules and have a very high cure rate, approaching $100 \%$. Invasive carcinomas account for the majority of breast cancers and have a much poorer prognosis. Malignant cell growth appears to start in the ducts and lobules and then invades the surrounding tissues and ultimately metastasises to other tissues and organs. A less common type is medullary carcinoma, comprising only c. $1-5 \%$ of breast cancers; this typically has heavy infiltrates of B-lymphocytes and a significantly better prognosis than the invasive ductal and lobular types. Length of disease free survival in breast cancer is unpredictable, with relapse occurring up to ten years post treatment and even beyond; it has been postulated that this may be due to host factors, including the nature and extent of the immune response.

\subsection{The immune response to breast cancer}

Most breast cancers contain infiltrates of lymphoid cells with large numbers of T-cells, including $\mathrm{CD}^{+}$and $\mathrm{CD} 8{ }^{+} \mathrm{T}$-cells, and variable numbers of B-cells, natural killer cells and macrophages. The degree of infiltration varies between different types of breast cancer with extensive lymphoid cell infiltrates in ductal carcinoma in situ and some invasive ductal and lobular carcinomas (Ben Hur et al., 2002). Most studies have focused on the role of cytotoxic T-cells in tumour immunity, with variable success in attempting to suppress tumour growth by boosting the $\mathrm{T}$-cell response to tumour-associated antigens. Relatively few studies have addressed the role of B-cells and humoral immunity in response to cancers, including breast cancer, despite the observation that c. $40 \%$ of ductal breast carcinomas have significant B-cell infiltration.

There is increasing evidence that B-cells play important dual opposing roles in the immune response to tumours; on the one hand as antigen presenting cells and producers of cytotoxic antibodies effective at killing tumour cells by antibody-dependent cell-mediated cytotoxicity (ADCC) and complement-dependent cell lysis, and as tumour antigen-presenting cells capable of very efficient T-cell activation; on the other hand as promoters of inflammation aiding tumour progression (de Visser, Korets, \& Coussens, 2005; de Visser, Eichten, \& Coussens, 2006). These seemingly contradictory effects may be due to the difference between a specific, high affinity immune response to antigen versus a low affinity, polyclonal response, or even suppression of the cytotoxic immune response via regulatory B-cells (Mauri, 2010). The importance of antibodies in eliminating tumours is clearly demonstrated by the results of treatment of breast cancer patients with humanised monoclonal antibodies (MAbs) specific for the epidermal growth factor receptor HER-2 (trastuzumab/herceptin and pertuzumab). Not only is herceptin effective in slowing down the progression of established metastatic disease, it has also recently been demonstrated to prevent the emergence of metastases when given as an adjuvant treatment (Hortobagyi, 2005). Pertuzumab has also yielded promising results in clinical trials (Bianco, 2004). Synergistic effects between herceptin and pertuzumab suggest promising new approaches to therapy using cocktails of antibodies (Nahta, Hung, \& Esteva, 2004) and elucidation of the molecular structure of the herceptin Fab/HER-2 complex (Cho et al., 2003) allows rational design of therapeutic anti-HER-2 antibodies. MAbs specific for other tumour-associated antigens (TAAs) are needed to work synergistically with trastuzumab and to treat patients who do not overexpress HER-2. 
Several molecules have been identified that are either over-expressed, mutated, or structurally modified on tumour cells and are therefore potential targets for immunotherapy, including HER-1, HER-2, MUC-1 and p53 (Taylor-Papadimitriou et al., 2002). Some TAAs appear to overcome tolerance and induce a natural immune response as a result of mutation or altered expression; humoral immune responses to these antigens in breast cancer patients are associated with better early disease stage-specific survival (Angelopoulou et al., 2000; Visco et al., 2000; von Mensdorff-Pouilly et al., 2000) and anti-MUC-1 antibodies are cytotoxic to tumour cells (Snijdewint et al., 2001). TAA-specific tumour infiltrating (TIL) B-lymphocytes and recombinant antibodies have been isolated from both tumour (Kotlan et al., 2000; Kotlan et al., 2005) and lymph nodes (Petrarca et al., 1999; Rothe et al., 2004) of medullary and ductal carcinoma patients, showing that they are responding specifically to the tumour. Evasion of the immune response by the tumour can be overcome by passive immunotherapy or active immunisation regimes. B-cells actively responding in the draining lymph node and tumour are therefore ideal sources to study the immune response to the tumour and provide the most relevant source of potentially therapeutic antibodies.

\subsection{Ductal carcinoma infiltrating lymphocytes are clustered into germinal centres}

We and others found infiltrating lymphocytes in ductal carcinomas were aggregated into clusters containing T-cells, B-cells and follicular dendritic cells with plasmablasts/plasma cells in and around the aggregates (Coronella et al., 2002; Nzula, Going, \& Stott, 2003a). These cell clusters appeared to be similar to those seen in the target tissues of autoimmune diseases except that there was no mantle zone (also absent in the salivary glands of patients with Sjögren's syndrome (Stott et al., 1998)), so we examined whether they were responding as germinal centres.

\subsection{The Ig V-gene repertoire and clonal proliferation of B-cells in ductal carcinoma}

We cloned and sequenced 401 rearranged $\mathrm{Ig} \mathrm{V}_{\mathrm{H}}$-genes from microdissected tumourinfiltrating B-cell foci of 7 patients with invasive ductal carcinoma and $271 \mathrm{~V}_{\mathrm{H}}$-genes from paired sentinel lymph nodes of 3 of the patients. 15 sets of $\mathrm{V}_{\mathrm{H}^{-}}$genes from clonally related Bcells within individual foci were identified by their shared $\mathrm{V}_{\mathrm{H}}, \mathrm{D}, \mathrm{J}_{\mathrm{H}}$ and CDR3 sequences, showing that proliferating, mutating B-cell clones were present in lymphoid foci and that these foci were undergoing a germinal centre response within the tumour, similar to the ectopic germinal centres we have observed in the target tissues of autoimmune diseases (Fig. 10). There was preferential usage of certain $\mathrm{V}_{\mathrm{H}}, \mathrm{D} \& \mathrm{~J}_{\mathrm{H}}$ exons, indicating selection of Bcells expressing antigen receptors encoded by these gene combinations. $\mathrm{V}_{\mathrm{H}} \& \mathrm{~V}_{\mathrm{L}}$-genes from proliferating B-cell clones contained numerous mutations, demonstrating that the somatic hypermutation machinery was switched on within the cell cluster, again characteristic of a germinal centre response. Analysis of the pattern of mutations showed that the B-cell clones are undergoing an antigen-driven response accompanied by selection of specific mutations and affinity maturation in situ. Clone founder cells were of both naïve and memory B-cell type, showing that a secondary response involving memory B-cells was taking place, but also new B-cells that had not previously encountered antigen moved into cell clusters and were stimulated by antigen. We also cloned rearranged $\mathrm{V}_{\mathrm{H}^{-} \text {-genes from microdissected }}$ germinal centres in the paired sentinel lymph node and identified proliferating, hypermutating B-cell clones there too. These also revealed selection for particular $\mathrm{V}_{\mathrm{H}} \& \mathrm{~J}_{\mathrm{H}^{-}}$ genes showing selection by antigen for B-cells expressing these genes during the immune response but we did not find evidence that members of the same B-cell clones had migrated 
from the sentinel node to the tumour; this could have been due to insufficient sample sizes (Nzula, Going \& Stott, 2003a; Simsa et al., 2005).
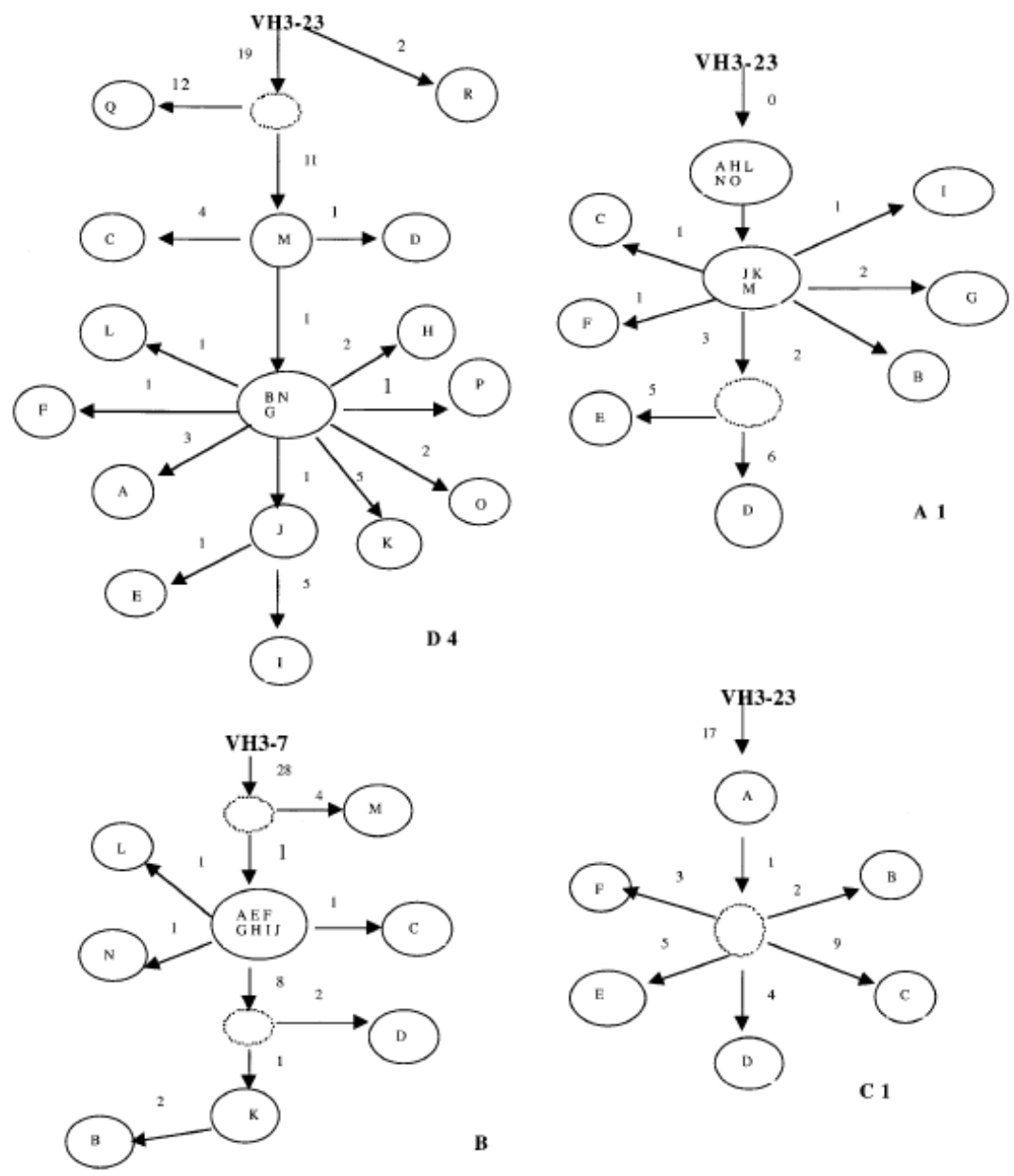

B

Fig. 10. Examples of proliferating, hypermutating B-cell clones from the breast tumours of four ductal carcinoma patients.

The best matching germline $\mathrm{V}_{\mathrm{H}}$-gene is shown at the origin of each tree. The founder rearranged $\mathrm{V}_{\mathrm{H}}$-genes of three of these B-cell clones already appear to be mutated, implying that they originated from memory Bcells, whereas clone A1 appears to have been founded by a naïve B-cell. Genealogical trees were constructed and mutations numbered as described in the legend to Figure 5. Reproduced from Nzula et al. (2003).

\subsection{Cloning and characterisation of ScFv antibodies}

In order to identify the antigens driving the immune response within the tumour, we reconstructed the antigen receptors expressed by germinal centre B-cells as scFv antibodies 
by cloning $\mathrm{V}_{\mathrm{H}}$ and $\mathrm{V}_{\mathrm{L}}$-genes into phagemid (pHEN2), as described in section 2.3, to generate $\mathrm{scFv}$-phage libraries expressing randomly assorted combinations of $\mathrm{V}_{\mathrm{H}}$ and $\mathrm{V}_{\mathrm{L}}$-genes. These "mini-libraries" were made from the B-cells in individual germinal centres within the tumour and are therefore much smaller and more restricted than the very large libraries normally made by random combination of large pools of $\mathrm{V}_{\mathrm{H}}$ and $\mathrm{V}_{\mathrm{L}}$-genes. Two scFv-phage mini-libraries were constructed from a germinal centre incorporating all the $\mathrm{V}_{\mathrm{H}}$-genes pooled from the largest proliferating B-cell clone (D4 in Fig. 10) linked randomly to either the rearranged $V_{\kappa}$-genes or the rearranged $V_{\lambda}$-genes amplified from the same germinal centre.

Tumour-binding scFv were selected from the mini-libraries by three or four cycles of panning and elution on a heterologous tumour homogenate pooled from breast tumours of 5 patients. During the panning cycles we observed exponential enrichment of the $V_{\lambda}$ minilibrary, but not the $\mathrm{V}_{\mathrm{K}}$ mini-library, indicating that $\mathrm{scFV}$ within the $\mathrm{V}_{\lambda}$ mini-library bind specifically to tumour-associated antigens (Fig. 11A). This is consistent with the scFvlibraries being derived from the same B-cell clone, since a single B-cell clone uses either a $\mathrm{K}$ or $\lambda$ light chain, not both. $13 \mathrm{scFv}$-phages binding to the tumour extract were cloned and their specificity for tumour tissue confirmed by ELISA. $7 \mathrm{scFv}$-phage clones that bound to the tumour extract were identified for further characterisation. All 7 used the same combination of $\mathrm{V}_{\mathrm{H}} 3-23$ with exons D1-26 \& $\mathrm{J}_{\mathrm{H}} 2$, expressed by B-cell clone D4, and the light chain gene $\mathrm{V}_{\lambda} 1 \mathrm{c}$ with $\mathrm{J}_{\lambda} 3 \mathrm{~b}$.

We also constructed two scFv-phage libraries from DNA extracted from a whole sample of tumour tissue, as described for the mini-libraries. The 2 libraries were panned on the same heterologous tumour homogenate as used with the mini-libraries. After 4 cycles of panning we observed an enrichment of several logs for both libraries, indicating the presence of tumour-specific antibodies (Fig. 11B). The enrichment of both global libraries shows that tumour-specific B-cells derived from independent B-cell clones were present in the tumour, as expected. $19 \mathrm{scFv}$-phages were cloned from the 2 global libraries and their specificity for tumour tissue confirmed by ELISA using the same tumour homogenate as source of antigen.

\subsection{Identification of the specificity of proliferating B-cells}

Since the scFvs from the $V_{H} / V_{\lambda}$ mini-library were derived from proliferating B-cell clone $\mathrm{D} 4$, their sequences and antigen specificities reveal the nature of the genes and antigen receptor specificities of the original germinal centre B-cells. We therefore sequenced the scFv clones that showed the strongest binding to the tumour extract and performed a Blast search of the Genbank gene database. The $\mathrm{V}_{\mathrm{H}} \mathrm{DJ} \mathrm{H}_{\mathrm{H}}$ heavy chain gene used by all members of B-cell clone D4 exhibited 89\% homology with a human anti-HER3 MAb (AF048774) and the $\mathrm{V}_{\lambda} \mathrm{J}_{\lambda}$ light chain gene, also used by the same B-cells, matched a human anti-EGFR antibody (DQ666353.1) with 96\% homology. These, and scFvs from the global libraries, were tested for binding to recombinant antigens from the epidermal growth factor receptor family: HER-2, HER-3 and HER-4, kindly provided by Genentech (San Francisco, USA) and Pharmexa A/S (Hørsholm, Denmark) by ELISA. Six scFvs from B-cell clone D4 and one from the global tumour library bound to recombinant HER-2, HER-3 \& HER-4, indicating that they recognised a shared epitope expressed by all three members of this EGFR family of receptors (Fig. 12). Specificity for HER-2, HER-3 \& HER-4 was confirmed using soluble scFv produced in the non-suppressor strain of E.coli. 

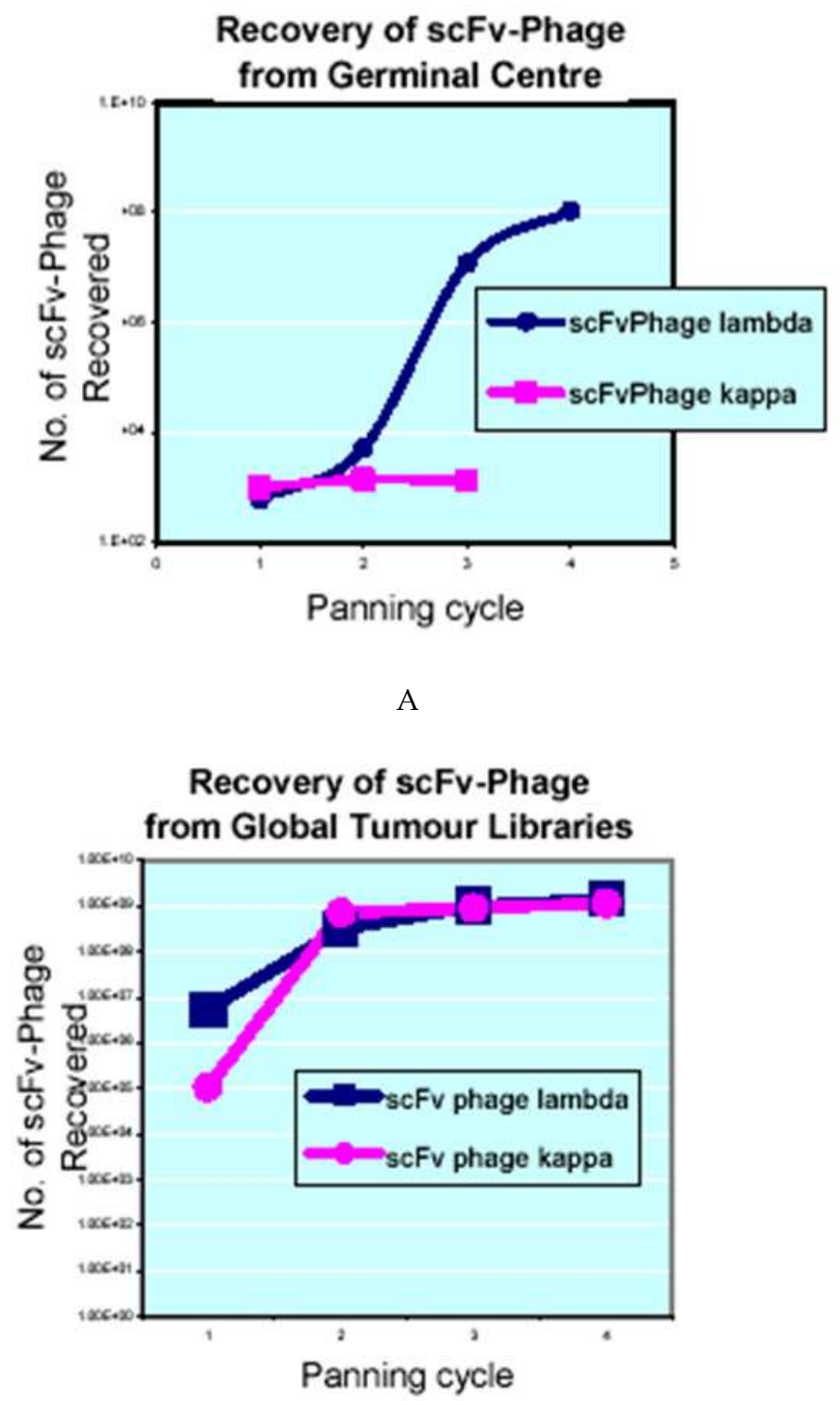

B

Fig. 11. Exponential enrichment of scFv-phage after panning and elution on a breast tumour extract

A. $\mathrm{V}_{\mathrm{H}} / \mathrm{VK}_{\mathrm{K}}$ and $\mathrm{V}_{\mathrm{H}} / \mathrm{V \lambda}$ scFv mini-libraries, using $\mathrm{V}_{\mathrm{H}}$-genes from B-cell clone D4, panned on pooled heterologous tumour extract The eluate from each panning was then subjected to further cycles of panning and elution; $B$. Global $\mathrm{V}_{\mathrm{H}} / \mathrm{VK}_{\mathrm{K}}$ and $\mathrm{V}_{\mathrm{H}} / \mathrm{V} \lambda \mathrm{scFv}$-phage libraries from a human breast tumour, panned on the same heterologous tumour extract as in $\mathrm{A}$. 


\section{Cloned scFv-phage from B-cell clone D4 \& a global tumour library bind Her-2, Her-3 \& Her-4}

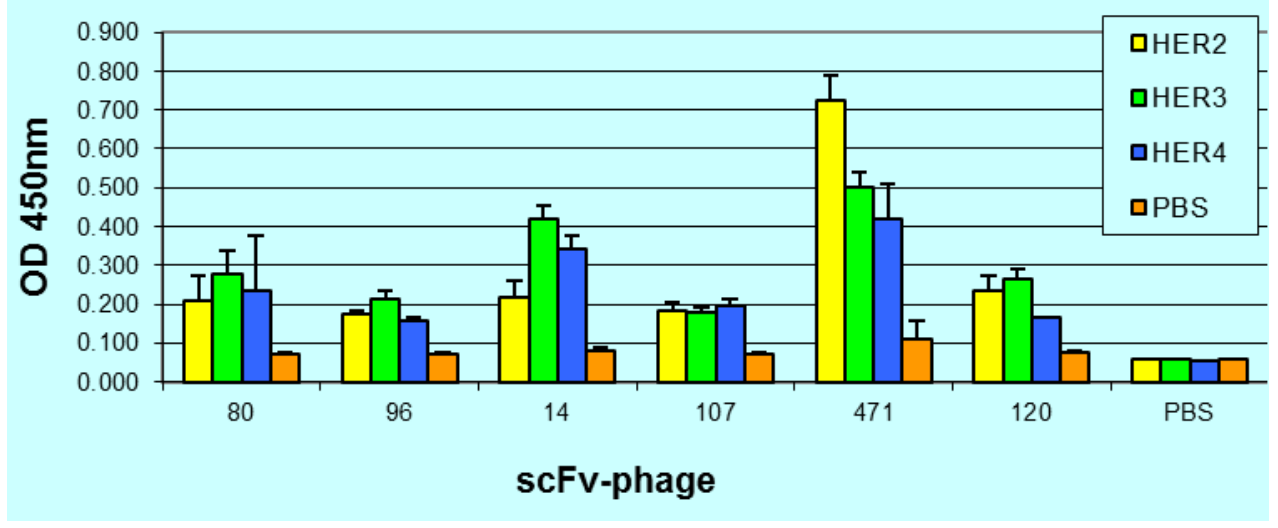

Fig. 12. EGFR family specificity of scFv antibodies cloned from a mammary carcinoma germinal centre.

Individual scFv-phage $(80,96,14 \& 107 \& 120)$ from B-cell clone D4, proliferating and mutating in a breast tumour, and scFv-phage (471), cloned from whole breast tumour tissue, bind to members of the epidermal growth factor receptor family Her-2, Her-3 \& Her-4.

\subsection{Conclusions}

Clusters of B-cells, T-cells and follicular dendritic cells form within human ductal breast carcinomas, resembling the ectopic germinal centres observed in the target tissues of patients with autoimmune diseases. These clusters of lymphoid cells contain clones of proliferating B-cells that are undergoing somatic hypermutation of their rearranged, Ig V(D)-J-genes and affinity selection of their B-cell receptors driven, in the case described here, by members of the epidermal growth factor receptor family, viz. HER2, HER3 and HER4. The antibodies produced during this response recognise an epitope shared by these 3 cell surface receptors, which are known to be overexpressed on breast carcinoma cells and several other types of carcinoma, including ovarian cancer. It is very probable that other tumour associated antigens are also able to stimulate a local B-cell response within the tumour, e.g. antibodies specific for a ganglioside were cloned from medullary carcinoma Bcells, although it is not clear whether these are involved in attacking the tumour (Kotlan et al., 2005).

Single chain $\mathrm{Fv}$ antibodies cloned from tumour germinal centre B-cells can readily be converted to complete antibodies by splicing their V-genes on to Ig constant regions of any desired isotype. These fully human antibodies can be produced in large quantities in a protein expression system and are therefore potential candidates for diagnosis, monitoring and therapy of breast and other types of cancer. 


\section{General conclusions}

It has become increasingly clear that infiltrating B- and T-lymphocytes organise themselves into ectopic lymphoid follicles and germinal centres within tissues undergoing inflammatory processes. This has been observed in several autoimmune diseases (Table 1), usually within the target organ or tissue, myasthenia gravis being the exception to the rule for reasons discussed in section 3.5. However, ectopic g.c.s are not restricted to autoimmune diseases but can also develop in other chronic inflammatory diseases, such as Crohn's disease and ulcerative colitis; at sites of infection such as the liver during chronic hepatitis C virus infection and the skin of oncocerciasis patients (Brattig et al., 2010); and in neoplasias, including lymphoma of the mucosal-associated lymphoid tissue associated with Sjögren's syndrome (Bombardieri et al., 2007a) and, as shown here, in breast cancer (Table 1).

How these ectopic g.c.s develop, their role in the pathology of autoimmune diseases, and in combating infections and malignancies is still unclear but evidence is beginning to emerge. Cytokines, chemokines and signalling molecules involved in lymphoid neogenesis in the secondary lymphoid organs also appear to be required for ectopic g.c. formation, including lymphotoxins- $\alpha, \beta$ and $\alpha_{1} \beta_{2}, \mathrm{TNFa}, \mathrm{Grb2}$, the chemokine receptor CXCR5, its ligand CXCL15, and the B-cell attracting chemokines CXCL13 and CCL21, in this case due to release of these molecules within the inflammatory environment, suggesting that g.c. formation may be secondary to inflammation (Aloisi \& Pujol-Borrell, 2006).

When reports first emerged of germinal centre-like structures within the target tissues of autoimmune diseases, there was some scepticism regarding whether these structures were involved in true germinal centre reactions. These doubts have now been dispelled. Identification of dark and light zones and a follicular dendritic cell network in intimate contact with B-cells was highly suggestive of a germinal centre reaction, especially when it was shown that autoantigen was trapped on the follicular dendritic cell processes, e.g. (SHIONO et al., 2003). Studies by us and other researchers have shown that the B-cells within ectopic germinal centres are activated to antigen-driven clonal proliferation, somatic hypermutation and class switching, similar to the response in orthotopic g.c.s responding to foreign antigens. That they switch on the somatic hypermutation machinery has been shown in several autoimmune diseases by sequencing studies of the expressed, rearranged Ig Vgenes cloned from microdissected g.c.s. This has been confirmed in the salivary gland g.c.s of Sjögren's patients and the synovial g.c.s of rheumatoid arthritis patients by identification of activation induced cytidine deaminase (AID), a key enzyme in somatic hypermutation and class switch recombination (Bombardieri et al., 2007b; Humby et al., 2009). Interestingly, expression of AID has recently been observed in hyperplastic fibroblasts of rheumatoid arthritis patients (Igarashi et al., 2010). Expression correlated with mutations in the $p 53$ gene and was induced by TNFa in vitro. AID is known to induce mutations in non-Ig genes at a lower frequency and it was suggested that the mutations of this tumour suppressor gene may be the cause of the fibroblast hyperplasia. Affinity maturation of B-cell receptors during somatic hypermutation has been demonstrated by analysis of replacement mutations, although early analyses failed to take into account the bias towards replacement mutations in the CDRs resulting from targeting of AID to sequence motifs such as RGYW. Final confirmation requires direct affinity measurements of autoantibodies cloned from germinal centre B-cells and/or by 3-D molecular modelling of the antigen-binding site bound to its epitope, as we have shown for anti-hen egg lysozyme antibodies produced in an orthotopic germinal centre reaction (Adams et al., 2003). 
In several cases it has been shown that the autoantibodies generated in ectopic g.c.s have similar specificities to the autoantibodies found in the blood, notably in Hashimoto's thyroiditis, Sjögren's syndrome and rheumatoid arthritis, suggesting that the g.c.s contribute to pathological mechanisms, although whether they are critical in the early stages of development of the disease, or only contribute to its maintenance once the initial tissue damage has commenced, has yet to be established. Production of cytokines and chemokines at sites of damage that attract lymphocytes and contribute to lymphoid neogenesis suggests that the latter may be the more likely scenario. Nevertheless, a detailed understanding of the mechanisms involved in generation of ectopic g.c. structures and maintenance of production of plasma cells and memory B-cells producing potentially pathogenic antibodies is essential for a full understanding of the pathology of autoimmune disease and holds promise for developing new methods of therapy, based on controlling this response or inducing immunological tolerance to the autoantigens.

Even more work needs to be done to determine the role of ectopic g.c.s in other diseases, including sterile and infectious chronic inflammatory diseases and cancer. What other types of cancer, in addition to breast cancer and lymphoma, induce germinal centre reactions within the tumour and the nature of their response in elimination of cancer cells have yet to be determined. The identification of intra-tumour g.c.s producing antibodies and memory Bcells with specificity for members of the epidermal growth factor receptor family holds out hope that therapeutic vaccines can be developed to boost this response for therapy of breast cancer and, potentially other neoplasias, such as ovarian cancer, in which these molecules are overexpressed. Experimental approaches using mouse models of breast cancer support this optimism (Renard et al., 2003; Renard \& Leach, 2007; Mukhopadhyay, MS in preparation). Cloning of antibodies against tumour-associated antigens from intra-tumour g.c.s is also a novel way of producing fully human antibodies for passive immunotherapy.

\section{Acknowledgements}

We wish to thank Professors Nick Willcox and Angela Vincent, F.R.S. (Institute for Molecular Medicine, University of Oxford, U.K.), Paul Garside and Iain McInnes (Institute of Infection, Immunity \& Inflammation, University of Glasgow, U.K.) for critically reading the manuscript and their helpful suggestions. We also wish to thank all the people who have worked in D.I. Stott's research group and those of his collaborators whose work contributed to the results described here, especially Gary Sims, Michael Matthews, Sazini Nzula and Anne-Sophie Rouziere, whose data on myasthenia gravis and ductal carcinoma are presented in this chapter. Any errors and oversights are entirely our own.

The original research described in this chapter was funded by The Wellcome Trust, the Scottish Executive Health Dept. Chief Scientist Office, Cancer Research UK, the Dr. Robert Mairs Trust and the Medical Research Council.

\section{References}

Adams, C. L., MacLeod, M. K. L., Milner-White, E. J., Aitken, R., Garside, P., \& Stott, D. I. 2003, "Complete analysis of the B-cell response to a protein antigen, from in vivo germinal centre formation to 3-D modelling of affinity maturation", Immunology, vol. 108, pp. 274-287. 
Allen, C. D. C., Okada, T., \& Cyster, J. G. 2007, "Germinal-Center Organization and Cellular Dynamics", Immunity, vol. 27, pp. 190-202.

Aloisi, F. \& Pujol-Borrell, R. 2006, "Lymphoid neogenesis in chronic inflammatory diseases", Nature Reviews Immunology, vol. 6, pp. 205-217.

Amemiya, K., Granger, R. P., \& Dalakas, M. C. 2000, "Clonal restriction of T-cell receptor expression by infiltrating lymphocytes in inclusion body myositis persists over time. Studies in repeated muscle biopsies", Brain, vol. 123 ( Pt 10), pp. 2030-2039.

Angelopoulou, K., Yu, H., Bharaj, B., Giai, M., \& Diamandis, E. P. 2000, "p53 gene mutation, tumor p53 protein overexpression, and serum p53 autoantibody generation in patients with breast cancer.", Clin.Biochem., vol. 33, pp. 53-62.

Arahata, K. \& Engel, A. G. 1984, "Monoclonal antibody analysis of mononuclear cells in myopathies. I: Quantitation of subsets according to diagnosis and sites of accumulation and demonstration and counts of muscle fibers invaded by T cells", Ann.Neurol., vol. 16, no. 2, pp. 193-208.

Armengol, M. P., Juan, M., Lucas-Martin, A., Fernandez-Figueras, M. T., Jaraquemada, D., Gallart, T., \& Pujol-Borrell, R. 2001, "Thyroid autoimmune disease: demonstration of thyroid antigen-specific $B$ cells and recombination-activating gene expression in chemokine-containing active intrathyroidal germinal centers", American Journal of Pathology, vol. 159, pp. 861-873.

Astorri, E., Bombardieri, M., Gabba, S., Peakman, M., Pozzilli, P., \& Pitzalis, C. 2010, "Evolution of Ectopic Lymphoid Neogenesis and In Situ Autoantibody Production in Autoimmune Nonobese Diabetic Mice: Cellular and Molecular Characterization of Tertiary Lymphoid Structures in Pancreatic Islets", The Journal of Immunology, vol. 185, pp. 3359-3368.

Beltman, J. B., Allen, C. D. C., Cyster, J. G., \& de Boer, R. J. 2011, "B cells within germinal centers migrate preferentially from dark to light zone", Proceedings of the National Academy of Sciences, vol. 108, pp. 8755-8760.

Ben Hur, H., Cohen, O., Schneider, D., Gurevich, P., Halperin, R., Bala, U., Mozes, M., \& Zusman, I. 2002, "The role of lymphocytes and macrophages in human breast tumorigenesis: an immunohistochemical and morphometric study", Anticancer Res, vol. 22, pp. 1231-1238.

Berrih-Aknin, S., Ruhlmann, N., Bismuth, J., Cizeron-Clairac, G., Zelman, E., Shachar, I., Dartevelle, P., De Rosbo, N. K., \& Le Panse, R. 2009, "CCL21 overexpressed on lymphatic vessels drives thymic hyperplasia in myasthenia", Ann.Neurol., vol. 66, pp. 521-531.

Bianco, A. R. 2004, "Targeting c-erbB2 and other receptors of the c-erbB family: rationale and clinical applications", J Chemother., vol. 16 Suppl 4, pp. 52-54.

Bohan, A. \& Peter, J. B. 1975a, "Polymyositis and dermatomyositis (first of two parts)", N.Engl.J.Med., vol. 292, no. 7, pp. 344-347.

Bohan, A. \& Peter, J. B. 1975b, "Polymyositis and dermatomyositis (second of two parts)", N.Engl.J.Med., vol. 292, no. 8, pp. 403-407.

Bombardieri, M., Barone, F., Humby, F., Kelly, S., McGurk, M., Morgan, P., Challacombe, S., De Vita, S., Valesini, G., Spencer, J., \& Pitzalis, C. 2007a, "Activation-induced cytidine deaminase expression in follicular dendritic cell networks and interfollicular large B cells supports functionality of ectopic lymphoid neogenesis in 
autoimmune sialoadenitis and MALT lymphoma in Sjogren's syndrome", The Journal of Immunology, vol. 179, pp. 4929-4938.

Bombardieri, M., Barone, F., Humby, F., Kelly, S., McGurk, M., Morgan, P., Challacombe, S., De Vita, S., Valesini, G., Spencer, J., \& Pitzalis, C. 2007b, "Activation-Induced Cytidine Deaminase Expression in Follicular Dendritic Cell Networks and Interfollicular Large B Cells Supports Functionality of Ectopic Lymphoid Neogenesis in Autoimmune Sialoadenitis and MALT Lymphoma in Sjogren's Syndrome", The Journal of Immunology, vol. 179, pp. 4929-4938.

Bradshaw, E. M., Orihuela, A., McArdel, S. L., Salajegheh, M., Amato, A. A., Hafler, D. A., Greenberg, S. A., \& O'Connor, K. C. 2007, "A local antigen-driven humoral response is present in the inflammatory myopathies", The Journal of Immunology, vol. 178, no. 1, pp. 547-556.

Brattig, N. W., Tenner-Racz, K., Korten, S., Hoerauf, A., \& Buttner, D. W. 2010, "Immunohistology of ectopic secondary lymph follicles in subcutaneous nodules from patients with hyperreactive onchocerciasis (sowda)", Parasitol.Res, vol. 107, pp. 657-666.

Brink, R. 2007, "Germinal-Center B Cells in the Zone", Immunity, vol. 26, pp. 552-554.

Canete, J. D., Santiago, B., Cantaert, T., Sanmarti, R., Palacin, A., Celis, R., Graell, E., GilTorregrosa, B., Baeten, D., \& Pablos, J. L. 2007, "Ectopic lymphoid neogenesis in psoriatic arthritis", Annals Rheumatic Disease, vol. 66, pp. 720-726.

Cardona, A., Garchon, B., Vernet der Garabedian, E., Morel, P., Gajdos, P., \& Bach, J.-F. 1994, "Human IgG monoclonal autoantibodies against muscle acetylcholine receptor: direct evidence for clonal heterogeneity of the anti-self humoral response in myasthenia gravis", J.Neuroimmunol., vol. 53, p. 9.

Chalk, C. H., Murray, N. M., Newsom-Davis, J., O'Neill, J. H., \& Spiro, S. G. 1990, "Response of the Lambert-Eaton myasthenic syndrome to treatment of associated small-cell lung carcinoma", Neurology, vol. 40, pp. 1552-1556.

Cho, H. S., Mason, K., Ramyar, K. X., Stanley, A. M., Gabelli, S. B., Denney, D. W., Jr., \& Leahy, D. J. 2003, "Structure of the extracellular region of HER2 alone and in complex with the Herceptin Fab", Nature, vol. 421, pp. 756-760.

Chung, L., Genovese, M. C., \& Fiorentino, D. F. 2007, "A pilot trial of rituximab in the treatment of patients with dermatomyositis", Arch.Dermatol., vol. 143, no. 6, pp. 763767.

Cooper, M. A., Willingham, D. L., Brown, D. E., French, A. R., Shih, F. F., \& White, A. J. 2007, "Rituximab for the treatment of juvenile dermatomyositis: a report of four pediatric patients", Arthritis Rheum., vol. 56, no. 9, pp. 3107-3111.

Coronella, J. A., Spier, C., Welch, M., Trevor, K. T., Stopeck, A. T., Villar, H., \& Hersh, E. M. 2002, "Antigen-Driven Oligoclonal Expansion of Tumor-Infiltrating B Cells in Infiltrating Ductal Carcinoma of the Breast", The Journal of Immunology, vol. 169, pp. 1829-1836.

Coronella, J. A., Telleman, P., Kingsbury, G. A., Truong, T. D., Hays, S., \& Junghans, R. P. 2001, "Evidence for an antigen-driven humoral immune response in medullary ductal breast cancer", Cancer Research, vol. 61, pp. 7889-7899.

Dalakas, M. C. 2004, "The molecular pathophysiology in inflammatory myopathies", La Revue de Medecine Interne, vol. 25, no. Supplement 1, p. S14-S16. 
Dalakas, M. C. \& Hohlfeld, R. 2003, "Polymyositis and dermatomyositis.", Lancet.362(9388):971-82.

Dalakas, M. C., Illa, I., Gallardo, E., \& Juarez, C. 1997, "Inclusion body myositis and paraproteinemia: incidence and immunopathologic correlations", Ann.Neurol., vol. 41, no. 1 , pp. $100-104$.

Darlow, J. M. \& Stott, D. I. 2005, "VH replacement in immunoglobulin genes", Immunology, vol. 114, pp. 155-165.

de Visser, K. E., Korets, L. V., \& Coussens, L. M. 2005, "De novo carcinogenesis promoted by chronic inflammation is B lymphocyte dependent", Cancer Cell, vol. 7, pp. 411-423.

de Visser, K. E., Eichten, A., \& Coussens, L. M. 2006, "Paradoxical roles of the immune system during cancer development", Nature Reviews Cancer, vol. 6, pp. 24-37.

Di Noia, J. M. \& Neuberger, M. S. 2007, "Molecular Mechanisms of Antibody Somatic Hypermutation", Annual Review of Biochemistry, vol. 76, pp. 1-22.

Drachman, D. B. 1994, "Myasthenia gravis", New England J.Med., vol. 330, pp. 1797-1810.

Engel, A. G. \& Arahata, K. 1984, "Monoclonal antibody analysis of mononuclear cells in myopathies. II: Phenotypes of autoinvasive cells in polymyositis and inclusion body myositis", Ann.Neurol., vol. 16, no. 2, pp. 209-215.

Farrar, J., Portolano, S., Willcox, N., Vincent, A., Jacobson, L., Newsom-Davis, J., Rapoport, B., \& McLachlan, S. M. 1997, "Diverse Fab specific for acetylcholine receptor epitopes from a myasthenia gravis thymus combinatorial library.", International Immunology, vol. 9, pp. 1311-1318.

Fostieri, E., Beeson, D., \& Tzartos, S. J. 2000, "The conformation of the main immunogenic region on the alpha-subunit of muscle acetylcholine receptor is affected by neighboring receptor subunits", FEBS Lett., vol. 481, pp. 127-130.

Fyhr, I. M., Moslemi, A. R., Mosavi, A. A., Lindberg, C., Tarkowski, A., \& Oldfors, A. 1997, "Oligoclonal expansion of muscle infiltrating T cells in inclusion body myositis", J.Neuroimmunol., vol. 79, no. 2, pp. 185-189.

Genta, R. M., Hamner, H. W., \& Graham, D. Y. 1993, "Gastric lymphoid follicles in Helicobacter pylori infection: frequency, distribution, and response to triple therapy", Hum.Pathol., vol. 24, pp. 577-583.

Gerhard, N., Krenn, V., Magalhaes, R., Morawietz, L., Brandlein, S., \& Konig, A. 2002, "IgVH-genes analysis from psoriatic arthritis shows involvement of antigenactivated synovial B-lymphocytes", Z.Rheumatol., vol. 61, pp. 718-727.

Ghosh, S., Steere, A. C., Stollar, B. D., \& Huber, B. T. 2005, "In situ diversification of the antibody repertoire in chronic Lyme arthritis synovium", J.Immunol., vol. 174, pp. 2860-2869.

Graus, Y. F., de Baets, M. H., Parren, P. W. H. I., Berrih-Aknin, S., Wokke, J., van Breda Vriesman, P. J., \& Burton, D. R. 1997, "Human anti-nicotinic acetylcholine receptor recombinant Fab fragments isolated from thymus-derived phage display libraries from myasthenia gravis patients reflect predominant specificities in serum and block the action of pathogenic serum antibodies", J.Immunol., vol. 158, pp. 19191929.

Greenberg, S. A., Bradshaw, E. M., Pinkus, J. L., Pinkus, G. S., Burleson, T., Due, B., Bregoli, L., O'Connor, K. C., \& Amato, A. A. 2005, "Plasma cells in muscle in inclusion body myositis and polymyositis", Neurology, vol. 65, no. 11, pp. 1782-1787. 
Greenberg, S. A., Sanoudou, D., Haslett, J. N., Kohane, I. S., Kunkel, L. M., Beggs, A. H., \& Amato, A. A. 2002, "Molecular profiles of inflammatory myopathies", Neurology, vol. 59, no. 8, pp. 1170-1182.

Hauser, A. E., Shlomchik, M. J., \& Haberman, A. M. 2007, "In vivo imaging studies shed light on germinal-centre development", Nature Reviews Immunology, vol. 7, pp. 499504 .

Hershberg, U., Uduman, M., Shlomchik, M. J., \& Kleinstein, S. H. 2008, "Improved methods for detecting selection by mutation analysis of Ig V region sequences", International Immunology, vol. 20, pp. 683-694.

Hill, M. E., SHIONO, H., Newsom-Davis, J., \& Willcox, N. 2008, "The myasthenia gravis thymus: a rare source of human autoantibody-secreting plasma cells for testing potential therapeutics", J.Neuroimmunol., vol. 201-202, pp. 50-56.

Hofbauer, M., Wiesener, S., Babbe, H., Roers, A., Wekerle, H., Dornmair, K., Hohlfeld, R., \& Goebels, N. 2003, "Clonal tracking of autoaggressive T cells in polymyositis by combining laser microdissection, single-cell PCR, and CDR3-spectratype analysis", Proc.Natl.Acad.Sci.U.S.A, vol. 100, no. 7, pp. 4090-4095.

Hortobagyi, G. N. 2005, "Trastuzumab in the Treatment of Breast Cancer", The New England Journal of Medicine, vol. 353, pp. 1734-1736.

Humby, F., Bombardieri, M., Manzo, A., Kelly, S., Blades, M. C., Kirkham, B., Spencer, J., \& Pitzalis, C. 2009, "Ectopic Lymphoid Structures Support Ongoing Production of Class-Switched Autoantibodies in Rheumatoid Synovium", PLoS Medicine, vol. 6, pp. 0001-0017.

Igarashi, H., Hashimoto, J., Tomita, T., YOSHIKAWA, H., \& Ishihara, K. 2010, "TP53 mutations coincide with the ectopic expression of activation-induced cytidine deaminase in the fibroblast-like synoviocytes derived from a fraction of patients with rheumatoid arthritis", Clinical \& Experimental Immunology, vol. 161, pp. 71-80.

Jang, I. K., Cronshaw, D. G., Xie, L. k., Fang, G., Zhang, J., Oh, H., Fu, Y. X., Gu, H., \& Zou, Y. 2011, "Growth-factor receptor-bound protein-2 (Grb2) signaling in B cells controls lymphoid follicle organization and germinal center reaction", Proceedings of the National Academy of Sciences, vol. 108, pp. 7926-7931.

Kaiserling, E. 2001, "Newly-formed lymph nodes in the submucosa in chronic inflammatory bowel disease", Lymphology, vol. 34, pp. 22-29.

Klein, U. \& Dalla-Favera, R. 2008, "Germinal centres: role in B-cell physiology and malignancy", Nature Reviews Immunology, vol. 8, pp. 22-33.

Knecht, H., Saremaslani, P., \& Hedinger, C. 1981, "Immunohistological findings in Hashimoto's thyroiditis, focal lymphocytic thyroiditis and thyroiditis de Quervain. Comparative study", Virchows Archiv - Abteilung A Pathologische Anatomie, vol. 393, pp. 215-231.

Kotlan, B., Simsa, P., Gruel, N., Foldi, J., Fridman, W. H., Petranyi, G., \& Teillaud, J. L. 2000, "A scFv phage display mini library generated from the immunoglobulin repertoire of breast medullary carcinoma infiltrating B lymphocytes", Dis.Markers, vol. 16, pp. 25-27.

Kotlan, B., Simsa, P., Teillaud, J. L., Fridman, W. H., Toth, J., McKnight, M., \& Glassy, M. C. 2005, "Novel Ganglioside Antigen Identified by B Cells in Human Medullary Breast Carcinomas: The Proof of Principle Concerning the Tumor-Infiltrating B Lymphocytes", The Journal of Immunology, vol. 175, pp. 2278-2285. 
Krystufkova, O., Vallerskog, T., Barbasso, H. S., Mann, H., Putova, I., Belacek, J., Malmstrom, V., Trollmo, C., Vencovsky, J., \& Lundberg, I. E. 2008, "Increased serum levels of B-cell activating factor (BAFF) in subsets of patients with idiopathic inflammatory myopathies", Annals of the Rheumatic Diseases.

Lang, B. \& Vincent, A. 2009, "Autoimmune disorders of the neuromuscular junction", Curr.Opin.Pharmacol., vol. 9, pp. 336-340.

Le Panse, R., Bismuth, J., Cizeron-Clairac, G., Weiss, J. M., Cufi, P., Dartevelle, P., De Rosbo, N. K., \& Berrih-Aknin, S. 2010, "Thymic remodeling associated with hyperplasia in myasthenia gravis", Autoimmunity, vol. 43, pp. 401-412.

Le Panse, R., Cizeron-Clairac, G., Bismuth, J., \& Berrih-Aknin, S. 2006, "Microarrays reveal distinct gene signatures in the thymus of seropositive and seronegative myasthenia gravis patients and the role of CC chemokine ligand 21 in thymic hyperplasia", The Journal of Immunology, vol. 177, pp. 7868-7879.

Leavy, O. 2010, "B cells: Illuminating the dark zone", Nature Reviews Immunology, vol. 11, p. 8.

Levine, T. D. M. 2005, "Rituximab in the Treatment of Dermatomyositis: An Open-Label Pilot Study.", Arthritis \& Rheumatism, vol. 52, no. 2, pp. 601-607.

Liversidge, J., Dick, A., Cheng, Y.-F., Scott, G. B., \& Forrester, J. V. 1993, "Retinal antigen specific lymphocytes, TCR-gamma delta T cells and CD5 ${ }^{+} \mathrm{B}$ cells cultured from the vitreous in acute sympathetic ophthalmitis", Autoimmunity, vol. 15, pp. 257-266.

Maddison, P. \& Lang, B. 2008, "Paraneoplastic neurological autoimmunity and survival in small-cell lung cancer", J.Neuroimmunol., vol. 201-202, pp. 159-162.

Mantegazza, R., Andreetta, F., Bernasconi, P., Baggi, F., Oksenberg, J. R., Simoncini, O., Mora, M., Cornelio, F., \& Steinman, L. 1993, "Analysis of T cell receptor repertoire of muscle-infiltrating $\mathrm{T}$ lymphocytes in polymyositis. Restricted $\mathrm{V}$ alpha/beta rearrangements may indicate antigen-driven selection", J.Clin.Invest, vol. 91, no. 6, pp. 2880-2886.

Manzo, A. \& Pitzalis, C. 2007, "Lymphoid tissue reactions in rheumatoid arthritis", Autoimmunity Reviews, vol. 7, pp. 30-34.

Matthews, I., Sims, G. P., Ledwidge, S., Stott, D. I., Beeson, D., Willcox, N., \& Vincent, A. 2002, "Antibodies to Acetylcholine Receptor in Parous Women with Myasthenia: Evidence for Immunization by Fetal Antigen", Laboratory Investigation, vol. 82, pp. 1407-1417.

Matzinger, P. 2007, "Friendly and dangerous signals: is the tissue in control?", Nat Immunol, vol. 8, pp. 11-13.

Mauri, C. 2010, "Regulation of immunity and autoimmunity by B cells", Current Opinion in Immunology, vol. 22, pp. 761-767.

Meraouna, A., Cizeron-Clairac, G., Panse, R. L., Bismuth, J., Truffault, F., Tallaksen, C., \& Berrih-Aknin, S. 2006, "The chemokine CXCL13 is a key molecule in autoimmune myasthenia gravis", Blood, vol. 108, pp. 432-440.

Mielnik, P., Wiesik-Szewczyk, E., Olesinska, M., Chwalinska-Sadowska, H., \& Zabek, J. 2006, "Clinical features and prognosis of patients with idiopathic inflammatory myopathies and anti-Jo-1 antibodies", Autoimmunity, vol. 39, no. 3, pp. 243-247.

Minton, K. 2011, "B cells: Short- and long-term memory", Nature Reviews Immunology, vol. 11, pp. 160-161. 
Mosnier, J.-F., Degott, C., Marcellin, P., Henin, D., Erlinger, S., \& Benhamou, J.-P. 1993, "The intraportal lymphoid nodule and its environment in chronic active hepatitis C: An Immunohistochemical study", Hepatology, vol. 17, pp. 366-371.

Nacionales, D. C., Weinstein, J. S., Yan, X. J., Albesiano, E., Lee, P. Y., Kelly-Scumpia, K. M., Lyons, R., Satoh, M., Chiorazzi, N., \& Reeves, W. H. 2009, "B Cell Proliferation, Somatic Hypermutation, Class Switch Recombination, and Autoantibody Production in Ectopic Lymphoid Tissue in Murine Lupus", The Journal of Immunology, vol. 182, pp. 4226-4236.

Nahta, R., Hung, M. C., \& Esteva, F. J. 2004, "The HER-2-Targeting Antibodies Trastuzumab and Pertuzumab Synergistically Inhibit the Survival of Breast Cancer Cells", Cancer Research, vol. 64, pp. 2343-2346.

Nemazee, D. 2006, "Receptor editing in lymphocyte development and central tolerance", Nature Reviews Immunology, vol. 6, pp. 728-740.

Nzula, S., Going, J. J., \& Stott, D. I. 2003a, "Antigen-driven clonal proliferation, somatic hypermutation and selection of B-lymphocytes infiltrating human ductal breast carcinoma", Cancer Res., vol. 63, pp. 3275-3280.

Nzula, S., Going, J. J., \& Stott, D. I. 2003b, "The role of B lymphocytes in breast cancer: a review and current status", Cancer Therapy, vol. 1, pp. 353-362.

Park, C. S. \& Choi, Y. S. 2005, "How do follicular dendritic cells interact intimately with B cells in the germinal centre?", Immunology, vol. 114, pp. 2-10.

Patakas, A., Platt, A. M., Butcher, J. P., Maffia, P., McInnes, I. B., Brewer, J. M., Garside, P., \& Benson, R. A. 2011, "Putative existence of reciprocal dialogue between Tfh and B cells and its impact on infectious and autoimmune disease", Immunol Lett., vol. In press.

Petrarca, C., Casalino, B., Mensdorff-Pouilly, S., Rughetti, A., Rahimi, H., Scambia, G., Hilgers, J., Frati, L., \& Nuti, M. 1999, "Isolation of MUC1-primed B lymphocytes from tumour-draining lymph nodes by immunomagnetic beads", Cancer Immunology, Immunotherapy, vol. 47, pp. 272-277.

Poea-Guyon, S., Christadoss, P., Le Panse, R., Guyon, T., De Baets, M., Wakkach, A., Bidault, J., Tzartos, S., \& Berrih-Aknin, S. 2005, "Effects of cytokines on acetylcholine receptor expression: implications for myasthenia gravis", The Journal of Immunology, vol. 174, pp. 5941-5949.

Prineas, J. W. 1979, "Multiple sclerosis: presence of lymphatic capillaries and lymphoid tissue in the brain and spinal cord", Science, vol. 203, pp. 1123-1125.

Renard, V. \& Leach, D. R. 2007, "Perspectives on the development of a therapeutic HER-2 cancer vaccine", Vaccine, vol. 25 Suppl 2, p. B17-B23.

Renard, V., Sonderbye, L., Ebbehoj, K., Rasmussen, P. B., Gregorius, K., Gottschalk, T., Mouritsen, S., Gautam, A., \& Leach, D. R. 2003, "HER-2 DNA and Protein Vaccines Containing Potent Th Cell Epitopes Induce Distinct Protective and Therapeutic Antitumor Responses in HER-2 Transgenic Mice", The Journal of Immunology, vol. 171, pp. 1588-1595.

Rider, L. G. 2007, "The heterogeneity of juvenile myositis", Autoimmun.Rev., vol. 6, no. 4, pp. 241-247.

Rosenfeld, M. R. \& Dalmau, J. 2010, "Update on paraneoplastic and autoimmune disorders of the central nervous system", Semin.Neurol., vol.30, pp. 320-331. 
Rothe, A., Klimka, A., Tur, M. K., Pfitzner, T., Huhn, M., Sasse, S., Mallmann, P., Engert, A., \& Barth, S. 2004, "Construction of phage display libraries from reactive lymph nodes of breast carcinoma patients and selection for specifically binding human single chain Fv on cell lines", Int.J Mol.Med, vol. 14, pp. 729-735.

Salajegheh, M., Pinkus, J. L., Amato, A. A., Morehouse, C., Jallal, B., Yao, Y., \& Greenberg, S. A. 2010, "Permissive environment for B-cell maturation in myositis muscle in the absence of B-cell follicles", Muscle E Nerve, vol. 42, no. 4, pp. 576-583.

Seitz, S., Schneider, C. K., Malotka, J., Nong, X., Engel, A. G., Wekerle, H., Hohlfeld, R., \& Dornmair, K. 2006, "Reconstitution of paired T cell receptor alpha- and beta-chains from microdissected single cells of human inflammatory tissues", Proc.Natl.Acad.Sci.U.S.A, vol. 103, no. 32, pp. 12057-12062.

Serafini, B., Rosicarelli, B., Magliozzi, R., Stigliano, E., \& Aloisi, F. 2004, "Detection of ectopic B-cell follicles with germinal centers in the meninges of patients with secondary progressive multiple sclerosis", Brain Pathol., vol. 14, pp. 164-174.

Shiono, H., Roxanis, I., Zhang, W., Sims, G. P., Meager, A., Jacobson, L. W., Liu, J. L., Matthews, I., Wong, Y. L., Bonifati, M., Micklem, K., Stott, D. I., Todd, J. A., Beeson, D., Vincent, A., \& Willcox, N. 2003, "Scenarios for autoimmunization of T and B cells in myasthenia gravis", Ann.N.Y.Acad.Sci., vol. 998, pp. 237-256.

Sims, G. P., Hiroyuki, S., Willcox, N., \& Stott, D. I. 2001, "Somatic Hypermutation and Selection of B Cells in Thymic Germinal Centers Responding to Acetyl Choline Receptor in Myasthenia Gravis", J.Immunol., vol. 167, pp. 1935-1944.

Simsa, P., Teillaud, J. L., Stott, D. I., Toth, J., \& Kotlan, B. 2005, "Tumor-infiltrating B cell immunoglobulin variable region gene usage in invasive ductal breast carcinoma", Pathol Oncol.Res, vol. 11, pp. 92-97.

Snijdewint, F. G., Mensdorff-Pouilly, S., Karuntu-Wanamarta, A. H., Verstraeten, A. A., Livingston, P. O., Hilgers, J., \& Kenemans, P. 2001, "Antibody-dependent cellmediated cytotoxicity can be induced by MUC1 peptide vaccination of breast cancer patients", Int.J Cancer, vol. 93, pp. 97-106.

Stolte, M. \& Eidt, S. 1989, "Lymphoid follicles in antral mucosa: immune response to Campylobacter pylori?", J Clin.Pathol., vol. 42, pp. 1269-1271.

Stott, D. I., Hiepe, F., Hummel, M., Steinhauser, G., \& Berek, C. 1998, "Antigen-driven clonal proliferation of B cells within the target tissue of an autoimmune disease. The salivary glands of patients with Sjögren's syndrome.", J.Clin.Invest., vol. 102, pp. 938-946.

Stott, D. I. \& Sims, G. P. 2000, "Application of scFv-phage display to analysis of B-cell clones proliferating in the salivary glands of a patient with Sjögren's syndrome", Disease Markers, vol. 16, pp. 21-23.

Swofford, D. L. 1993, "PAUP: Phylogenetic analysis using parsimony, version 3.1,".

Taylor-Papadimitriou, J., Burchell, J. M., Plunkett, T., Graham, R., Correa, I., Miles, D., \& Smith, M. 2002, "MUC1 and the immunobiology of cancer", J Mammary.Gland.Biol.Neoplasia., vol. 7, pp. 209-221.

Victora, G. D., Schwickert, T. A., Fooksman, D. R., Kamphorst, A. O., Meyer-Hermann, M., Dustin, M. L., \& Nussenzweig, M. C. (12-11-2010)Germinal Center Dynamics Revealed by Multiphoton Microscopy witháa Photoactivatable Fluorescent Reporter. Cell 143[4], 592-605. 
Vincent, A. 2002, "Unravelling the pathogenesis of myasthenia gravis", Nature Revs.Immunol., vol. 2, pp. 797-804.

Vincent, A. \& et al. 1997, "Thymoma and autoimmune neurological disorders," in Epithelial Tumours of the Thymus, A. Marx \& H. K. Muller-Hermelink, eds., Plenum Press, New York, pp. 195-204.

Visco, V., Bei, R., Moriconi, E., Gianni, W., Kraus, M. H., \& Muraro, R. 2000, "ErbB2 immune response in breast cancer patients with soluble receptor ectodomain.", Am.J.Pathol., vol. 156, pp. 1417-1424.

von Mensdorff-Pouilly, S., Verstraeten, A. A., Kenemans, P., Snijdewint, F. G. M., Kok, A., Van Kamp, G. J., Paul, M. A., Van Diest, P. J., Meijer, S., \& Hilgers, J. 2000, "Survival in Early Breast Cancer Patients Is Favorably Influenced by a Natural Humoral Immune Response to Polymorphic Epithelial Mucin", Journal of Clinical Oncology, vol. 18, p. 574.

Wallace, W. A. H., Howie, S. E. M., Krajewski, A. S., \& Lamb, D. 1996, "The immunological architecture of B-lymphocyte aggregates in cryptogenic fibrosing alveolitis", J.Pathol., vol. 178, pp. 323-329.

Weiser, A. A., Wittenbrink, N., Zhang, L., Schmelzer, A. I., Valai, A., \& Or-Guil, M. 2011, "Affinity maturation of B cells involves not only a few but a whole spectrum of relevant mutations", International Immunology, vol. 23, pp. 345-356.

Yoshitake, T., Masunaga, A., Sugawara, I., Nakamura, H., Itoyama, S., \& Oka, T. 1994, "A comparative histological and immunohistochemical study of thymomas with and without myasthenia gravis", Surgery Today, vol. 24, pp. 1044-1049.

Zampieri, S., Ghirardello, A., Iaccarino, L., Tarricone, E., Gambari, P. F., \& Doria, A. 2005, "Anti-Jo-1 antibodies", Autoimmunity, vol. 38, no. 1, pp. 73-78.

Zuckerman, N. S., Howard, W. A., Bismuth, J., Gibson, K., Edelman, H., Berrih-Aknin, S., Dunn-Walters, D., \& Mehr, R. 2010, "Ectopic GC in the thymus of myasthenia gravis patients show characteristics of normal GC", Eur.J Immunol, vol. 40, pp. 11501161. 


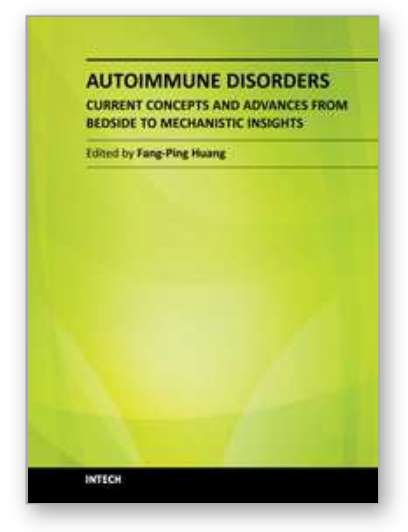

\author{
Autoimmune Disorders - Current Concepts and Advances from \\ Bedside to Mechanistic Insights \\ Edited by Dr. Fang-Ping Huang
}

ISBN 978-953-307-653-9

Hard cover, 614 pages

Publisher InTech

Published online 14, November, 2011

Published in print edition November, 2011

Autoimmune disorders are caused due to break down of the immune system, which consequently fails in its ability to differentiate "self" from "non-self" in the context of immunology. The diseases are intriguing, both clinically and immunologically, for their diversified clinical phenotypes and complex underlying immunological mechanisms. This book offers cutting-edge information on some of the specific autoimmune disease phenotypes, respective diagnostic and prognostic measures, classical and new therapeutic options currently available, pathogenesis and underlying mechanisms potentially involved, and beyond. In the form of Open Access, such information is made freely available to clinicians, basic scientists and many others who will be interested regarding current advances in the areas. Its potential readers will find many of the chapters containing in-depth analysis, interesting discussions and various thought-provoking novel ideas.

\title{
How to reference
}

In order to correctly reference this scholarly work, feel free to copy and paste the following:

David I. Stott and Donna McIntyre (2011). The Ectopic Germinal Centre Response in Autoimmune Disease and Cancer, Autoimmune Disorders - Current Concepts and Advances from Bedside to Mechanistic Insights, Dr. Fang-Ping Huang (Ed.), ISBN: 978-953-307-653-9, InTech, Available from:

http://www.intechopen.com/books/autoimmune-disorders-current-concepts-and-advances-from-bedside-tomechanistic-insights/the-ectopic-germinal-centre-response-in-autoimmune-disease-and-cancer

\section{INTECH}

open science | open minds

\author{
InTech Europe \\ University Campus STeP Ri \\ Slavka Krautzeka 83/A \\ 51000 Rijeka, Croatia \\ Phone: +385 (51) 770447 \\ Fax: +385 (51) 686166 \\ www.intechopen.com
}

\author{
InTech China \\ Unit 405, Office Block, Hotel Equatorial Shanghai \\ No.65, Yan An Road (West), Shanghai, 200040, China \\ 中国上海市延安西路65号上海国际贵都大饭店办公楼 405 单元 \\ Phone: +86-21-62489820 \\ Fax: $+86-21-62489821$
}


(C) 2011 The Author(s). Licensee IntechOpen. This is an open access article distributed under the terms of the Creative Commons Attribution 3.0 License, which permits unrestricted use, distribution, and reproduction in any medium, provided the original work is properly cited. 